\title{
EFFECT OF DIFFERENT SOWING METHODS AND NITROGEN RATES ON YIELD AND QUALITY OF WINTER WHEAT IN LOESS PLATEAU OF CHINA
}

\author{
NOOR, H. - KHAN, S. -SUn, M. ${ }^{*}$ YU, S. - REN, A. - YANG, Z. - HOU, F. - LI, L. - WANG, Q. - \\ GAO, Z.
}

College of Agriculture, Shanxi Agricultural University, Taigu 030801, Shanxi, China

*Corresponding author

e-mail: sm_sunmin@126.com; phone/fax: +86-354-628-7187

(Received $19^{\text {th }}$ Jan 2020; accepted $2^{\text {nd }}$ Jul 2020)

\begin{abstract}
In order to explore the optimum amount of nitrogen application in different sowing methods of winter wheat, a field experiment was conducted at Wenxi experimental site of Shanxi Agriculture University (2017-2018), The two sowing methods were (I) Wide Space Sowing (WSS), and (II) Drilling Sowing (DS) with seven nitrogen treatments: $0 \mathrm{~kg} \cdot \mathrm{hm} 90 \mathrm{~kg} \cdot \mathrm{hm}^{-2}, 180 \mathrm{~kg} \cdot \mathrm{hm}^{-2}, 210 \mathrm{~kg} \mathrm{hm}{ }^{-2}, 240 \mathrm{~kg} \mathrm{hm}-$ ${ }^{2}, 270 \mathrm{~kg} \mathrm{hm}^{-2}$ and $300 \mathrm{~kg} \mathrm{hm}^{-2}$. (WSS) significantly increased the number of spikes yield and number of kernels per spike, nitrogen rate which ultimately increased the yield. The yield was the highest at $240 \mathrm{~kg} \cdot \mathrm{hm}^{-2}$ and $210 \mathrm{~kg} \cdot \mathrm{hm}^{-2}$, respectively. Nitrogen application significantly increased the Net Photosynthesis Rate $(\mathrm{Pn})$, intercellular carbon dioxide concentration $(\mathrm{Ci})$ and transpiration rate $(\mathrm{Tr})$ and decreased the stomatal conductance (Gs) of post-anthesis flag leaves. Wide space sowing wheat with $\mathrm{N}_{240}$ was the best. Compared with other nitrogen application rates, (WSS) with the nitrogen of $240 \mathrm{~kg} \cdot \mathrm{hm}^{-2}$ increased nitrogen accumulation in all growth stage while nitrogen uptake efficiency, nitrogen use efficiency and nitrogen productive efficiency were the highest at $90 \mathrm{~kg} \cdot \mathrm{hm}^{-2}$ and lowest at $300 \mathrm{~kg} \cdot \mathrm{hm}^{-2}$. The accumulation of soluble sugar in the middle and late stages increased and the sucrose content and starch content increased in each period after anthesis. The content of each protein component increased the albumin which was the highest at $240 \mathrm{~kg} \cdot \mathrm{hm}^{-2}$ and the globulin was the highest at $270 \mathrm{~kg} \cdot \mathrm{hm}^{-2}$. The prolamin and glutenin (storage protein) were the highest at $300 \mathrm{~kg} \cdot \mathrm{hm}^{-2}$ and in $240 \mathrm{~kg} \cdot \mathrm{hm}^{-2}$. The protein content at $300 \mathrm{~kg} \cdot \mathrm{hm}^{-2}$, and protein yield at $240 \mathrm{~kg} \cdot \mathrm{hm}^{-2}$ were significantly improved compared to other nitrogen application rates. The sedimentation value, falling value, formation time, development time, wet gluten and the gluten index increased and the water absorption rate was relatively stable as nitrogen fertilizer increased.
\end{abstract}

Keywords: nitrogen use efficiency, WSS, soil water content, photosynthesis characteristics, grain protein

\section{Introduction}

The yield of winter wheat (Triticum aestivum L.) in dryland area is unstable and substantially lower than the average yield in other areas of China and other European countries. Stabilizing the yield of dryland wheat and improving the overall production and grain quality of dryland areas have always been the main task of research for cultivation work in the arid regions of North China (Li et al., 2002; Ma et al., 2005). The world's largest Loess Plateau is located in northern China, covering Shanxi, eastern Gansu, Shaanxi, and northern Henan provinces (Encyclopedia et al., 2013). The Loess Plateau in China covers about 0.65 million $\mathrm{km}^{2}$ area and has 108 million population (Wang et al., 2010). The Loess Plateau has a semiarid climate with low and variable rainfall from 300-700 mm ( $\mathrm{Li}$ et al., 1992). Due to the lack of irrigation resources and deep and sparse groundwater, most of the agriculture is dryland farming, which completely depends on the precipitation (Zhang et al., 2009).

Technological quality of wheat is a very complex character, which depends on the genetic potential of genotypes, applied technology and agro ecological conditions. 
Mineral nutrition, especially nitrogen nutrition, highly influences the technological quality. Nitrogen, in interaction with other elements of mineral nutrition, has important influence on yield and technological quality of wheat (Pepó et al., 2005; Horvat et al., 2006). Wheat is one of the most important food crops in the world and it is also an important food crop in China and its production plays an important role in China's national economic production. Improving yield and quality in production has always been an important task for wheat cultivation workers. The yield and quality of wheat are affected by varieties, environmental factors and cultivation measures (Mao et al., 2015). Different sowing methods such as drilling, wide space sowing and mulching are in practice for wheat cultivation which affect water consumption and yield (Wang et al., 2016).

In the Loess Plateau, a short summer fallow of about three months is practiced after the harvest of the previous winter wheat in late June and planting of the succeeding crop in late September to conserve soil water. Available soil moisture at sowing time depends on the tillage method used during the fallow period (Sun et al., 2018). Traditional sowing method (TS, drilled using a mechanical seeder, with rows spaced $20 \mathrm{~cm}$ apart without film mulching), is widely practiced on the Loess Plateau in China. Such sowing method without mulching does not conserve precipitation and soil moisture (Liu et al., 2005). Studied possibilities of direct drilling and reduced tillage in second crop silage corn. The direct seeding method gave the best result for mean of emergence dates and percentage of emerged seedling. The best result for silage yield was found in tillage combination. The lowest yield was found in the heavy-duty disc harrow tillage method. The direct seeding gives the best results for tillage efficiency parameters, such as fuel consumption, effective power requirement and field efficiency (Bayhan et al., 2006; Yalçın and Çakır et al., 2006).

The wide space and furrow sowing method, with wide space $(22-25 \mathrm{~cm}$ wide base and $12 \mathrm{~cm}$ height) and furrow (depth $8 \mathrm{~cm}$, sown into the top-edges of the furrow, rows spaced $12 \mathrm{~cm}$ ) by using an all-in-one machine for ridging, fertilization and sowing, is being promoted not only for conserving precipitation and decreasing soil water evaporation, but also for avoiding contamination of soil environment with plastic. Sun et al., 2015; Li et al., 2018 reported that various sowing methods influenced wheat yield due to changes in soil water storage and water-use efficiency on the Loess Plateau in China. However, it remained unclear how different sowing methods would influence soil bacterial diversity and abundance that contribute to the changes in soil quality and micro-environment (Mann et al., 2019). Compared with flat sowing, soil moisture is not easy to be lost under the sowing condition and its water retention performance is strong (Bergeron et al., 1949). Compared with conventional seeding three-dimensional uniform sowing can increase chlorophyll content promoted photosynthesis during grain filling and can significantly reduce the number of infertile spikelet's and increase wheat yield (Li et al., 2010; Zhao et al., 2019).

The work of sowing method along with the improvement of soil water status and quality, seedling establishment, quality and crop yield can also be increased mainly through improving water infiltration and retention (Yan et al., 2008). Photosynthesis in crops is changed by the addition of water and nitrogen and nitrogen nutrition is influenced. Tridimensional uniform sowing is a modified form of conventional drilling in which seeds are distributed evenly and in the same plane (Tao et al., 2018). High nitrogen use efficiency resulting in increased grain protein content may come from improved capacity of the grain to accrue nitrogen supply to the grains (Tribor et al., 
2002). Grain protein content decreased in the year with low precipitation $(335.0 \mathrm{~mm})$, while increased in the year with high precipitation $(673.1 \mathrm{~mm}),(534.7 \mathrm{~mm})$ (Sun et al., 2014). Nitrogen fertilizer expands soil fertility and crop productivity. Nitrogen is an essential mineral nutrient for plant growth (Wang et al., 2012; Ahmad et al., 2013).

Nitrogen fertilizer has a major input rate in the production of direct seeded winter wheat. In the past, recommended nitrogen application the spring using ammonium nitrate (Black et al., 1977). In China, farmers excessively apply nitrogen fertilizers because of their hope to sustain further grain yield increases but grain yield does not keep synchronous increase with excessive nitrogen application (Meng et al., 2016). Nitrogen application during the wheat growing season generally exceeds $320 \sim 350 \mathrm{~kg}$ nitrogen ha ${ }^{-1}$ however, some farmers uses rates as high as $750 \mathrm{~kg}$ nitrogen ha ${ }^{-1}$ (Lu et al., 2015). Therefore, achieving both high yield and high nitrogen simultaneously is a major challenge (Lu et al., 2014). The efficient recovery of fertilizer nitrogen by crops is desirable both for economic reasons and to minimize environmental problems. However, various studies in China have shown that nitrogen losses following the use of fertilizer can be high (Roelcke et al., 1994; Zhang et al., 1992). Available water and nitrogen are considered the most limiting factors in wheat production in most parts of the world, especially in arid and semi-arid regions (Gonzalez et al., 2010). Therefore, supplemental irrigation and nitrogen fertilizer application are required to match soil water stress and stabilize yields (Tavakkoli et al., 2004).

The highest nitrogen uptake in the growth period occurred from reviving stage to anthesis stage. The proportion of nitrogen accumulated in leaf and stem was high before the anthesis stage and the accumulated nitrogen rate in stem reached peak at the anthesis stage (Zhao et al., 2006). The objective of this study were to find the best sowing method and optimize doses of nitrogen level to increase the yield and quality of winter wheat crop. Wide space sowing (WSS) with $240 \mathrm{~kg} \cdot \mathrm{hm}^{-2}$ enhances photosynthetic characteristics of flag leaves and promotes dry matter accumulation, to achieve high yield in addition, it was showed that the nitrogen metabolism of the plants improved, which was beneficial to the improvement of sugar and protein content and the quality of wheat also improved.

\section{Materials and methods}

\section{Experimental site}

The field experiment was conducted at Wenxi experimental site of Shanxi Agriculture University located in the southeastern part of the Loess Plateau $\left(34^{\circ} 35^{\prime} \mathrm{N}\right.$ and $110^{\circ} 15^{\circ} \mathrm{E}$ ) from 2017-2018. It is a typical semi-arid area with an altitude of 450$700 \mathrm{~m}$. The average annual temperature is 11 to $13{ }^{\circ} \mathrm{C}$. The average annual rainfall is $450-630 \mathrm{~mm}, 60-70 \%$ of the rainfall is concentrated in July-September. Winter wheat and maize are the main crops, irrigation conditions start for winter wheat in midOctober to the beginning of June of the following year, for corn in mid-to-late June, it is harvested in early October of the same year. The total rainfall at the test site for 20172018 was $240.9 \mathrm{~mm}$, with rainfall for each month as shown in Figure 1 and soil base fertility is presented in Table 1 .

In wenxi experimental station where wheat was planted once a year without irrigation. Natural precipitation was the main source of water for crop cultivation in the same area and precipitation mainly concentrated in July-September, which was the 
fallow period of wheat. Precipitation from sowing to wintering and jointing to maturity were abundant, but the fallow period.

Table 1. Soil nutrient properties from experimental location in Shanxi. (Data source:

Meteorological Station of Shanxi, Wenxi)

\begin{tabular}{c|c|c}
\hline Soil nutrients & $\mathbf{2 0 1 7 - 2 0 1 8}$ & $\mathbf{2 0 1 7 - 2 0 1 8}$ \\
\hline Soil layer $(\mathrm{cm})$ & 0.20 & 20.40 \\
Organic matter $\left(\mathrm{g} \mathrm{kg}^{-1}\right)$ & 12.59 & 10.40 \\
Available phosphorous $\left(\mathrm{mg} \mathrm{kg}^{-1}\right)$ & 16.26 & 10.71 \\
Available potassium $\left(\mathrm{mg} \mathrm{kg}^{-1}\right)$ & 280.65 & 150.65 \\
$\mathrm{pH}$ & 7.89 & 8.02 \\
\hline
\end{tabular}

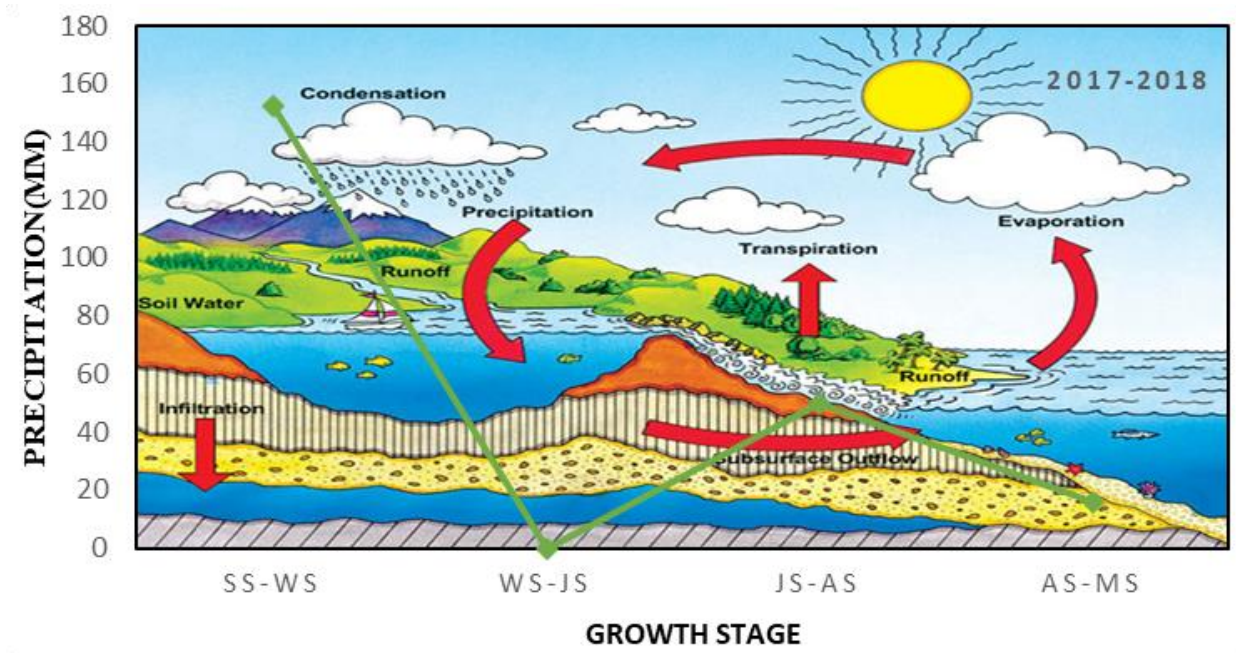

Figure 1. Precipitation during study year (2017-2018) in different growth stages of wheat at the experimental site in Wenxi. Fallow period: SS-WS, WS-JS, JS-AS, AS-MS: 20 Jun to 30 Sep; S$W$ (sowing-wintering): 01 Oct to $30 \mathrm{Nov}$; W-J (wintering-jointing): 1 Dec to $25 \mathrm{Apr} ; \mathrm{J}-\mathrm{A}$ (jointing-anthesis): 26 Apr to 1 May; A-M (anthesis-maturity):2 May to 9 Jun, total growth period and total precipitation, respectively

\section{Experimental design and treatments}

The wheat cultivar 'liangxing-99' used in this experiment was obtained from Wenxi Agriculture Jinnan. The two factors split-plot design was adopted and two sowing methods was set as (I) Wide Space Sowing (WSS) (II) Drilling Sowing (DS). The details of the machinery and sowing techniques are given in Table 2 and Figure 2. Nitrogen application amount was taken as the secondary area with seven nitrogen application levels set as $\mathrm{N}_{0}: 0 \mathrm{~kg} \mathrm{hm}^{-2}, \mathrm{~N}_{90}: 90 \mathrm{~kg} \mathrm{hm}^{-2}, \mathrm{~N}_{180}: 180 \mathrm{~kg} \mathrm{hm}^{-2}, \mathrm{~N}_{240}$ : $240 \mathrm{~kg} \mathrm{hm}^{-2}, \mathrm{~N}_{270}: 270 \mathrm{~kg} \mathrm{hm}^{-2}, \mathrm{~N}_{300}: 300 \mathrm{~kg} \mathrm{hm}^{-2}$. All treatments were replicated 3 times. The area of each plot was $30 \mathrm{~m}^{2}(5 \mathrm{~m} \times 6 \mathrm{~m})$. Winter wheat was sown in October in 2017 and 2018 and harvested in June of the following year. Stubble (about $25 \mathrm{~cm}$ high) was left in field after harvesting wheat. 
Table 2. Wide space sowing (WSS), drilling sowing (DS) details of sowing methods adopted during the experiment

\begin{tabular}{c|c|c|c}
\hline Sowing method & Sowing technique & Line spacing & Tillage \\
\hline $\begin{array}{c}\text { Wide space sowing } \\
\text { (WS) }\end{array}$ & 2BMF-12/6, tillage, auto-fertilization & Line space: $22-25 \mathrm{~cm}$ & $\begin{array}{c}\text { Sub-soiling, } \\
\text { rotary tillage }\end{array}$ \\
\hline $\begin{array}{c}\text { Drilling sowing } \\
\text { (DS) }\end{array}$ & $\begin{array}{c}\text { 2BXF-12Seed driller, Nonghaha } \\
\text { company, no-till, auto-fertilization }\end{array}$ & Line space: $20 \mathrm{~cm}$ & No tillage \\
\hline
\end{tabular}
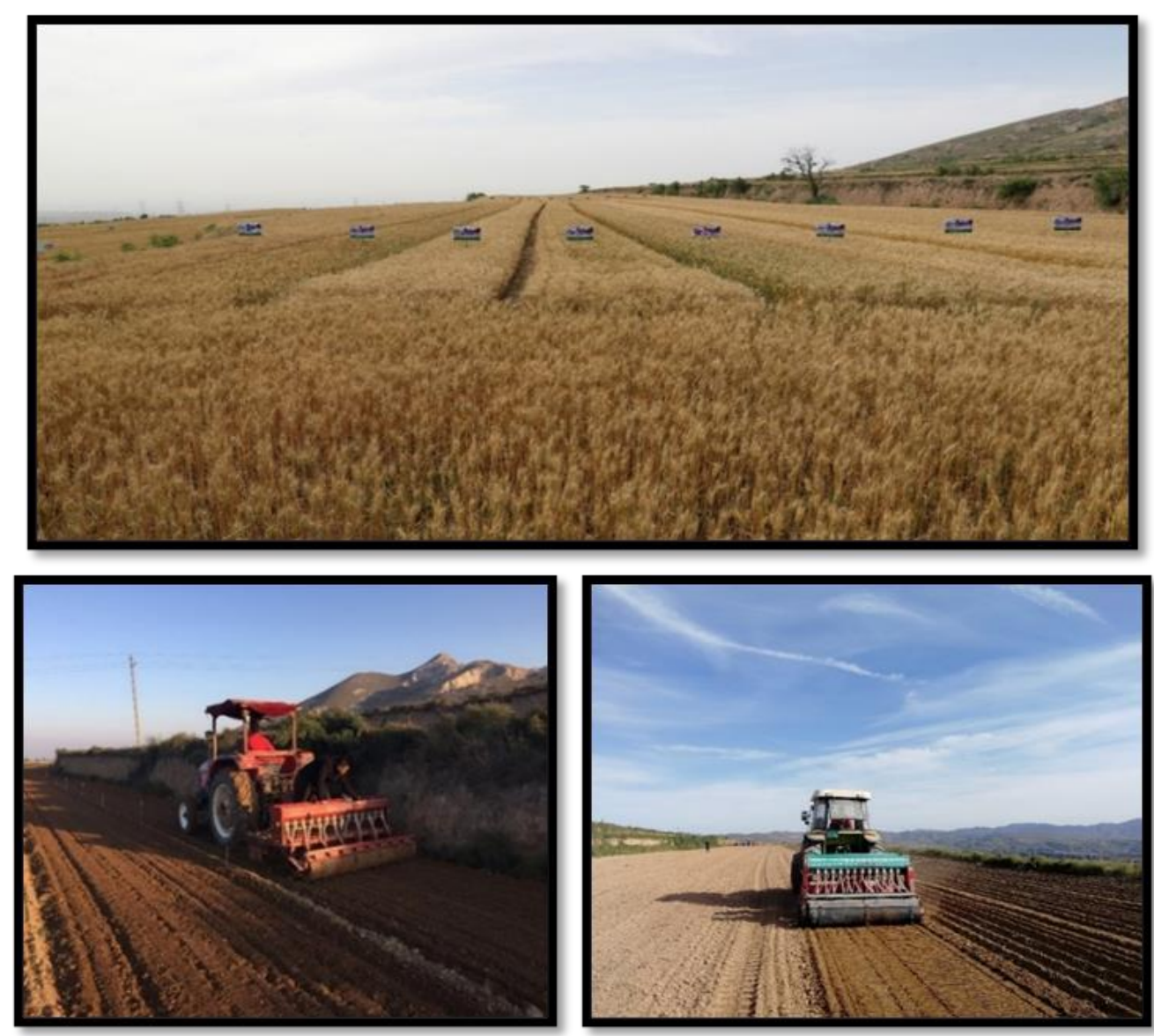

Figure 2. Field preparation at experimental site and tow sowing methods. (a) Wide space sowing (WSS). (b) Drilling sowing (DS) of Shanxi Agricultural University

After the previous corn harvest, the straw was returned to the field. Before sowing, the basal application of phosphate fertilizer and potash fertilizer, P2O5 $150 \mathrm{~kg} \cdot \mathrm{hm}^{-2}, \mathrm{~K} 2 \mathrm{O} 90$ $\mathrm{kg} \cdot \mathrm{hm}{ }^{-2}$ was applied to the soil. The sowing amount was $225 \mathrm{~kg} \cdot \mathrm{hm}^{-2}$, the nitrogen fertilizer was applied to the base ratio of $6: 4$ in the joint stage, with the irrigation of $60 \mathrm{~mm}$, with the conventional field management. And no fertilizer was applied during growth seasons. 


\section{Measurements}

\section{Determination of total tiller and plant nitrogen}

Number of tillers in the population: three parallel rows of wheat sample sections with seedling emergence were selected in each growth period, with an area of $0.667 \mathrm{~m}^{2}$ and the number of tillers in the population was investigated. After drying and comminution of plant organs in each growth period, the nitrogen content was determined by blue colorimetry of $\mathrm{H}_{2} \mathrm{SO}_{4}-\mathrm{H}_{2} \mathrm{O}_{2}$-indiophenol, which was calculated with reference to Li et al. (2018).

\section{Water consumption}

Water consumption in wheat fields was measured using a simplified formula as described below (Xue et al., 2019):

$$
E T=P-\Delta S
$$

where $\mathrm{P}$ is the effective precipitation $(\mathrm{mm})$ during that stage and $\Delta \mathrm{S}$ is reduction of soil water storage at each stage and was measured as $\Delta S=S_{1}-S_{2}$, where $S_{1}$ and $S_{2}$ were the soil water content at the beginning and end of the stage, respectively. Whereas, runoff and drainage were considered negligible.

The water consumption intensity $\left(\mathrm{CWR}, \mathrm{mm} \mathrm{d}^{-1}\right)$ was calculated as:

$$
C w R=\frac{E T_{i}}{d}
$$

where ETi is the water consumption ( $\mathrm{mm}$ ) of wheat in each growth stage and $\mathrm{d}$ is the number of days in the growth stage.

\section{Soil water storage}

At the sowing, wintering, jointing, anthesis and maturity of wheat growth stages, $0-300 \mathrm{~cm}$ soil layer was drilled, carefully packed into an aluminum box to determine soil moisture content. Oven drying method was used to measure the soil water content of every $20 \mathrm{~cm}$ soil. Soil water storage were calculated by using the following formula (Liang et al., 2019):

$$
\text { Soil water storage }(\mathrm{mm})=\frac{\text { wet soil weight }- \text { dry soil weight }}{\text { dry soil weight } \times 100 \% \times \text { soil thickness } \times \text { soil bulk density }}
$$

Changes in soil water storage ( $\triangle \mathrm{SWS}$ ) for a specific stage of wheat will be calculated as the difference between the soil water storage at the beginning (SWS1) and at the end of the growth stage (SWS2) as follow:

$$
\Delta \mathrm{SWS}=\mathrm{SWS} 1-\mathrm{SWS} 2
$$

The water consumption $(\mathrm{CA}, \mathrm{mm})$, percentage of $\mathrm{CA}$ to total water consumption $(\mathrm{CP}, \%)$, and daily water consumption $(\mathrm{CD}, \mathrm{mm})$ were calculated as follow:

$$
\begin{gathered}
\mathrm{CA}=\mathrm{P}+\mathrm{I}-\Delta \mathrm{SWS} \\
\mathrm{CP}=\mathrm{CAG} / \mathrm{CA}
\end{gathered}
$$




$$
\mathrm{CD}=\text { the } \mathrm{CAG} / \mathrm{d}
$$

where $\mathrm{P}$ is precipitation $(\mathrm{mm})$ during this period, $\mathrm{I}$ is the irrigation amount, CAG refers to water consumption at a certain stage, and $\mathrm{d}$ is the number of days in the growing stage.

$$
\mathrm{WUE}=\mathrm{Y} / \mathrm{ET}
$$

where WUE is water use efficiency $\left(\mathrm{kg} \mathrm{h}^{-1} \mathrm{~mm}^{-1}\right)$; $\mathrm{Y}$ is the yield of wheat $\left(\mathrm{kg} \mathrm{h}^{-1}\right)$.

\section{Determination of spike number}

Comparison of the spike of interest with the model spike occurs in an n-dimensional vector space, which dimensions are defined by the total spikelet number of the spike of interest. The geometrical difference in GYDAS between the two spikes is based on the scalar product of these two vectors:

$$
\cos \alpha(\vec{a}, \vec{b})=\frac{\vec{a} \cdot \vec{b}}{|\vec{a}| \cdot|\vec{b}|}
$$

Photosynthetic characteristics i.e. leaf photosynthetic rate, transpiration rate, intercellular carbon dioxide concentration and stomatal conductance of flag leaf were measured by CI-340 hand-held photosynthesis measurement system (USA) at 9:0011:00, 14 Days, 21 D, 28 D, after flowering.

\section{Determination of sucrose, soluble sugar and starch}

After flowering period listed growth consistent and the same day flowering of wheat spike and peeling grain was placed in the oven dried at $105^{\circ} \mathrm{C}$ for $20 \mathrm{~min}$ and then at 80 ${ }^{\circ} \mathrm{C}$ for 12 hours for dry weight. The quality and speed of weighing samples greatly affect the overall quality of the test. Then the grain was weighed and phenol method was used to determine the content of sucrose, and ketone color method was used to determine the total soluble total sugar content. $\mathrm{H}_{2} \mathrm{SO}_{4}-\mathrm{H}_{2} \mathrm{O}_{2}$-Phenol blue color method was used to determine the seed protein and its component content (Zhao et al., 2013).

\section{Determination of grain yield, grain protein yield}

At maturity, plants were randomly sampled from three $1 \mathrm{~m}^{2}$ areas from each plot to determine grain number spike ${ }^{-1}$ and 1,000 grain weight. All plants from the plots were harvested on 9 June 2017. Grains were air-dried whereas aboveground plant parts were oven dried until constant weight to determine the grain yield $\left(\mathrm{kg} \mathrm{ha}^{-1}\right)$ and dry biomass. The harvest index $(\mathrm{HI})$ was calculated dividing the grain yield by the aboveground dry biomass.

\section{Determination of wet gluten content processing quality}

The bromophenol blue water solution and isopropanol lactic acid mixture, and the settling values were determined by shock. The landing value was measured using the Landing Numerical Measurer (FN-IV). The Micro dough LAB, a micro powder instrument was produced by a Swedish company Botone (SCB) and it measured the fluidity of bread. The wet gluten content and gluten index were measured using the Gluten Index Meter (MJ-IIIB) quality analyzer. For Quality analysis dough mixed from $200 \mathrm{~g}$ flour was divided into small doughs weighted based on $0.25 \mathrm{~g}$ flour calculated as. 


$$
\text { Wet gluten }(\%)=\frac{100 \% \text { flour }+2 \mathrm{ml} \text { water }+10 \% \text { salt }}{100} \times 0.25 \mathrm{~g} \text { of flour }
$$

\section{Statistical analysis}

The different Data were subjected to analysis of variance (ANOVA) as split-plot design using DPS and SAS 9.0. Graphics were constructed using Microsoft Excel 2010-13. Mean values were calculated and significance of the difference between treatments was tested by LSD (least significant difference) method at the significance level of $\mathrm{P}=0.05$.

\section{Results}

\section{Nitrogen fertilizer on yield compositional factors}

Wheat yield and compositional factors were more common than regular strips with a significant increase in spike, yield and an increased number of spikes (Table 3). The number of spikes, spike shots and the weight of thousands of grains, yield with the increased nitrogen application showed the trend of first increase and then decrease. The yield and its three elements were the highest in $\mathrm{N}_{240}$ and spike number and yield were significantly different from other nitrogen treatment and under DS, the yield and its constituent elements was the highest in $\mathrm{N}_{210}$ and the spike and yield was significantly different from other nitrogen treatment. It can be seen WSS and DS, access can optimize the output of the three elements at the same time of WSS broadcast with $\mathrm{N}_{240}$ and DS casting $\mathrm{N}_{210}$ to achieve the increase of output. Drilling sowing (DS) and wide space sowing (WWS) showed significant increase in the number of spikes and yield. With the increased nitrogen rate, the three factors of yield increased first and then decreased. For WS and DS, the yield and its three elements are the highest at $240 \mathrm{~kg} \cdot \mathrm{hm}^{-2}$ and $210 \mathrm{~kg} \cdot \mathrm{hm}^{-2}$, respectively.

\section{Effect of different sowing methods and water consumption during the growth period for winter wheat}

Effect of nitrogen fertilizers on water use of wide space sowing (WSS) of wheat influence total water consumption during the growth period. With the increase of nitrogen application, the total water consumption in the growth period of WSS wheat increased first and then decreased (Fig. 3). The total water consumption in the growth period of $\mathrm{N}_{240}$ treatment was significantly higher than in other treatments and was the lowest without nitrogen application and the differences between $\mathrm{N}_{210}$ and $\mathrm{N}_{270}, \mathrm{~N}_{90}$ and $\mathrm{N}_{180}, \mathrm{~N} 0$ and $\mathrm{N}_{300}$ were not significant. It can be seen that WSS with $\mathrm{N}_{240}$ increased the total water consumption during the growth period of wheat, which was conducive to the growth and development.

\section{Effect of different sowing methods and nitrogen rates on water source of farmland and percentage for farmland water consumption}

With the increase of nitrogen application, the proportion of precipitation and water content of wheat fields decreased first and then increased and water consumption of soil, storage and its proportion increased (Table 4). The proportion of precipitation water consumption was the lowest in $\mathrm{N}_{240}$ and was the highest in $\mathrm{N}_{0}$ and $\mathrm{N}_{240}$ was different from other treatments and the proportion of water consumption was also the 
lowest in $\mathrm{N}_{240}$ and the highest in $\mathrm{N}_{0}$ but the difference between treatments were not significant and the soil water storage, water consumption and its proportion were the lowest and in $\mathrm{N}_{0}, \mathrm{~N}_{240}$ and $\mathrm{N}_{240}$ were significantly higher than other nitrogen applications. The wide space sowing (WSS) with $\mathrm{N}_{240}$ reduced the dependence of wheat on precipitation and irrigation during growth and enhanced the utilization of wheat to soil water storage.

Table 3. Effect of different sowing methods on grain protein and component contents of winter wheat

\begin{tabular}{|c|c|c|c|c|c|}
\hline $\begin{array}{l}\text { Sowing } \\
\text { method }\end{array}$ & $\begin{array}{c}\text { N rate } \\
\left(\mathbf{k g} \cdot \mathbf{h m}^{-2}\right)\end{array}$ & $\begin{array}{c}\text { Spike number } \\
\left(10^{4} \cdot \mathbf{h m}^{-2}\right)\end{array}$ & $\begin{array}{c}\text { Grain number } \\
\text { Per spike }\end{array}$ & $\begin{array}{c}\text { 1000-grain } \\
\text { weight }(\mathrm{g})\end{array}$ & $\begin{array}{c}\text { Yield } \\
\left(\mathrm{kg} \cdot \mathrm{hm}^{-2}\right)\end{array}$ \\
\hline \multirow{7}{*}{ WSS } & $\mathrm{N}_{0}$ & $688.25_{c}$ & $29.92_{b}$ & $36.42_{\mathrm{cd}}$ & $6433.31_{\mathrm{e}}$ \\
\hline & $\mathrm{N}_{90}$ & $705.75 b_{c}$ & $30.69_{a}$ & $37.32_{c}$ & $6938.22_{\mathrm{d}}$ \\
\hline & $\mathrm{N}_{180}$ & $716.50_{\mathrm{c}}$ & $29.73_{b}$ & $40.66_{b}$ & $7447.64^{\mathrm{c}}$ \\
\hline & $\mathrm{N}_{210}$ & $728.25_{c}$ & $30.56_{a}$ & $41.35_{\mathrm{ab}}$ & $7841.61_{b}$ \\
\hline & $\mathrm{N}_{240}$ & $823.25 \mathrm{a}$ & $31.52 \mathrm{a}$ & $42.58_{\mathrm{a}}$ & $9234.26_{a}$ \\
\hline & $\mathrm{N}_{270}$ & $758.75_{b}$ & $30.95^{\mathrm{a}}$ & $39.07_{b}$ & $8003.31_{\mathrm{b}}$ \\
\hline & $\mathrm{N}_{300}$ & $695.50_{c}$ & $28.08 b_{c}$ & $38.90_{\mathrm{c}}$ & $6684.08_{\mathrm{de}}$ \\
\hline \multirow{7}{*}{ DS } & $\mathrm{N}_{0}$ & $511.25 \mathrm{e}$ & $27.97 \mathrm{c}$ & $35.56_{d}$ & $4231.12_{\mathrm{h}}$ \\
\hline & $\mathrm{N}_{90}$ & $547.75 \mathrm{e}$ & $28.54_{b c}$ & $39.70_{\mathrm{b}}$ & $5139.00_{\mathrm{g}}$ \\
\hline & $\mathrm{N}_{180}$ & $560.25 \mathrm{e}$ & $29.88_{b}$ & $40.73_{b}$ & $5857.49_{\mathrm{f}}$ \\
\hline & $\mathrm{N}_{210}$ & $628.50 \mathrm{~d}$ & $30.40_{\mathrm{a}}$ & $42.10_{\mathrm{a}}$ & $6921.53_{d}$ \\
\hline & $\mathrm{N}_{240}$ & $587.50 \mathrm{~d}$ & $29.10_{\mathrm{b}}$ & $41.28_{\mathrm{ab}}$ & $6092.60_{\mathrm{f}}$ \\
\hline & $\mathrm{N}_{270}$ & $540.00 \mathrm{e}$ & $28.02_{\mathrm{bc}}$ & $39.92_{b}$ & $5087.64_{\mathrm{g}}$ \\
\hline & $\mathrm{N}_{300}$ & $503.75 \mathrm{f}$ & $27.20_{\mathrm{c}}$ & $36.84_{\mathrm{cd}}$ & $4356.07_{\mathrm{h}}$ \\
\hline
\end{tabular}

WSS, DS indicate wide space sowing, drilling sowing and sowing technique 2BMF-12/6, tillage, autofertilization WSS: wide space sowing. DS: 2BXF-12 seed driller, Nonghaha Company, no-till, autofertilization drilling sowing

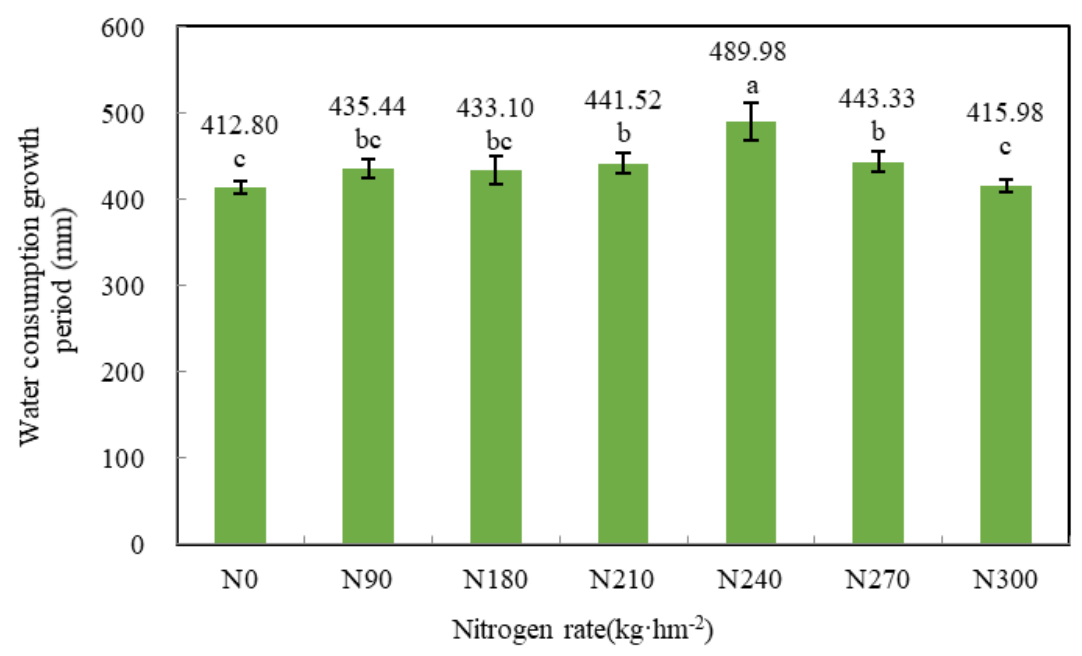

Figure 3. Effect of different sowing methods and nitrogen rate on water consumption of soil profile, of winter wheat. Different letters indicate significant difference among treatments at the significance level of $p \leq 0.05$ 
Table 4. Effect of different sowing methods and nitrogen rate on water resources of water consumption amount and ratio of winter wheat

\begin{tabular}{c|c|c|c|c|c|c}
\hline & \multicolumn{2}{|c|}{ Precipitation } & \multicolumn{2}{c|}{ Irrigation } & \multicolumn{2}{c}{ Soil water storage } \\
\cline { 2 - 7 } $\begin{array}{c}\text { N rate } \\
\left(\mathbf{h m}^{-2}\right)\end{array}$ & $\begin{array}{c}\text { Water } \\
\text { consumption } \\
\text { amount (mm) }\end{array}$ & $\begin{array}{c}\text { Proportion } \\
\text { ratio (\%) }\end{array}$ & $\begin{array}{c}\text { Water } \\
\text { consumption } \\
\text { amount (mm) }\end{array}$ & $\begin{array}{c}\text { Proportion } \\
\text { ratio (\%) }\end{array}$ & $\begin{array}{c}\text { Water } \\
\text { consumption } \\
\text { amount (mm) }\end{array}$ & $\begin{array}{c}\text { Proportion } \\
\text { ratio (\%) }\end{array}$ \\
\hline $\mathrm{N}_{0}$ & 218.30 & $52.89_{\mathrm{a}}$ & 60.00 & $14.54_{\mathrm{a}}$ & $134.50_{\mathrm{c}}$ & $32.58_{\mathrm{c}}$ \\
$\mathrm{N}_{90}$ & 218.30 & $50.14_{\mathrm{a}}$ & 60.00 & $13.78_{\mathrm{ab}}$ & $157.14_{\mathrm{b}}$ & $36.09_{\mathrm{b}}$ \\
$\mathrm{N}_{180}$ & 218.30 & $50.41_{\mathrm{a}}$ & 60.00 & $13.85_{\mathrm{ab}}$ & $154.80_{\mathrm{b}}$ & $35.74_{\mathrm{b}}$ \\
$\mathrm{N}_{210}$ & 218.30 & $49.44_{\mathrm{b}}$ & 60.00 & $13.59_{\mathrm{ab}}$ & $163.22_{\mathrm{b}}$ & $36.97_{\mathrm{b}}$ \\
$\mathrm{N}_{240}$ & 218.30 & $44.55_{\mathrm{c}}$ & 60.00 & $12.25_{\mathrm{b}}$ & $211.68_{\mathrm{a}}$ & $43.20_{\mathrm{a}}$ \\
$\mathrm{N}_{270}$ & 218.30 & $49.24_{\mathrm{b}}$ & 60.00 & $13.53_{\mathrm{ab}}$ & $165.03_{\mathrm{b}}$ & $37.22_{\mathrm{b}}$ \\
$\mathrm{N}_{300}$ & 218.30 & $52.48_{\mathrm{a}}$ & 60.00 & $14.42_{\mathrm{a}}$ & $137.68_{\mathrm{c}}$ & $33.10_{\mathrm{c}}$ \\
\hline
\end{tabular}

Different letters indicate significant difference among treatments at the significance level of $p \leq 0.05$

\section{Effect of different sowing methods and nitrogen rates on grain protein and components content}

The effect of nitrogen fertilizers on grain protein and its components were significantly different (Table 5). The contents of albumin and globulin (soluble protein) increased first and then decreased with the increase of nitrogen application. The highest value of albumin was in $\mathrm{N}_{240}$ and the difference between $\mathrm{N}_{270}$ and $\mathrm{N}_{300}$ were not significant. The highest value of albumin was $\mathrm{N}_{270}$ and the difference between $\mathrm{N}_{180}, \mathrm{~N}_{210}, \mathrm{~N}_{240}$ and $\mathrm{N}_{300}$ were not significant. The contents of glutenin (storage protein) increased with the increase of nitrogen application with the highest content of $\mathrm{N}_{300}$, but the difference of glutenin content was not significant compared with $\mathrm{N}_{270}$ and the content of glutenin $\mathrm{N}_{300}$ was significantly higher than that of other nitrogen application treatments compared with $\mathrm{N}_{90}$, $\mathrm{N}_{180}$ and $\mathrm{N}_{240}$ were the highest ratio of grain to alcohol but the difference was not significant. The protein contents were significantly higher than that of $\mathrm{N}_{300}$ and $\mathrm{N}_{240}$ and other nitrogen applications. The protein yield of $\mathrm{N}_{240}$ was significantly higher than that of other nitrogen treatments. It can be seen that nitrogen fertilizer has obvious regulation on storage protein and was more conducive to quality improvement.

Table 5. Effect of different sowing methods nitrogen rate on grain protein and component contents at maturity stage

\begin{tabular}{c|c|c|c|c|c|c|c}
\hline $\begin{array}{c}\mathbf{N} \text { rate } \\
\left(\mathbf{k g} \cdot \mathbf{h m}^{-2}\right)\end{array}$ & $\begin{array}{c}\text { Albumin } \\
(\boldsymbol{\%})\end{array}$ & $\begin{array}{c}\text { Globulin } \\
(\boldsymbol{\%})\end{array}$ & $\begin{array}{c}\text { Gliadin } \\
(\boldsymbol{\%})\end{array}$ & $\begin{array}{c}\text { Glutenin } \\
(\boldsymbol{\%})\end{array}$ & Glu/Gli & $\begin{array}{c}\text { Protein } \\
(\boldsymbol{\%})\end{array}$ & $\begin{array}{c}\text { Protein yield } \\
\left(\mathbf{k g} / \mathbf{h m}^{-2}\right)\end{array}$ \\
\hline $\mathrm{N}_{0}$ & $1.96_{\mathrm{c}}$ & $1.54_{\mathrm{d}}$ & $2.61_{\mathrm{d}}$ & $3.57_{\mathrm{e}}$ & $1.37_{\mathrm{ab}}$ & $10.75_{\mathrm{d}}$ & $755.79_{\mathrm{d}}$ \\
$\mathrm{N}_{90}$ & $2.09_{\mathrm{b}}$ & $1.71_{\mathrm{c}}$ & $2.88_{\mathrm{c}}$ & $4.00_{\mathrm{d}}$ & $1.39_{\mathrm{a}}$ & $11.24_{\mathrm{c}}$ & $857.56_{\mathrm{c}}$ \\
$\mathrm{N}_{180}$ & $2.12_{\mathrm{b}}$ & $1.80_{\mathrm{ab}}$ & $3.04_{\mathrm{c}}$ & $4.26_{\mathrm{d}}$ & $1.40_{\mathrm{a}}$ & $11.92_{\mathrm{c}}$ & $962.22_{\mathrm{c}}$ \\
$\mathrm{N}_{210}$ & $2.20_{\mathrm{b}}$ & $1.80_{\mathrm{ab}}$ & $3.94_{\mathrm{b}}$ & $5.24_{\mathrm{c}}$ & $1.33_{\mathrm{b}}$ & $13.40_{\mathrm{b}}$ & $1050.77_{\mathrm{b}}$ \\
$\mathrm{N}_{240}$ & $2.58_{\mathrm{a}}$ & $1.93_{\mathrm{a}}$ & $4.03_{\mathrm{b}}$ & $5.92_{\mathrm{b}}$ & $1.47_{\mathrm{a}}$ & $14.79_{\mathrm{a}}$ & $1282.54_{\mathrm{a}}$ \\
$\mathrm{N}_{270}$ & $2.46_{\mathrm{a}}$ & $1.95_{\mathrm{a}}$ & $4.30_{\mathrm{a}}$ & $5.81_{\mathrm{b}}$ & $1.35_{\mathrm{b}}$ & $14.03_{\mathrm{b}}$ & $1087.29_{\mathrm{b}}$ \\
$\mathrm{N}_{300}$ & $2.49_{\mathrm{a}}$ & $1.91_{\mathrm{a}}$ & $4.50_{\mathrm{a}}$ & $6.09_{\mathrm{a}}$ & $1.35_{\mathrm{b}}$ & $15.10_{\mathrm{a}}$ & $799.20_{\mathrm{d}}$ \\
\hline
\end{tabular}




\section{Effect of different sowing methods and nitrogen rates on net photosynthesis rate (Pn) of the post-flower flag leaves}

The concentration of carbon dioxide between the flag leave cells after wide space sowing (WSS) and wheat flower decreased gradually with the grouting process and the 0-7 days net photosynthesis rate increased with the amount of nitrogen applied after flowering showing a single peak increase trend (Fig. 4). The 14 days net photosynthesis rate after flowering was still the highest at $\mathrm{N}_{300}$ and not significantly different from $\mathrm{N}_{270}$ and $\mathrm{N}_{240}$, but after flowering 21 days and 28 days net photosynthesis rate increased with nitrogen application. After flowering 28 days was still the highest with $\mathrm{N}_{240}$, but the difference was not significant compared to $\mathrm{N}_{180}, \mathrm{~N}_{210}, \mathrm{~N}_{270}$ and $\mathrm{N}_{300}$. It can be seen that the addition of nitrogen fertilizer can significantly improve the net photosynthesis rate of the flag leaves after flowering, but the treatment effect of high nitrogen $\left(\mathrm{N}_{270}, \mathrm{~N}_{300}\right)$ in the later grouting was weakened and the wide space sowing (WSS) with $\mathrm{N}_{240}$ could sustain the whole grout period.

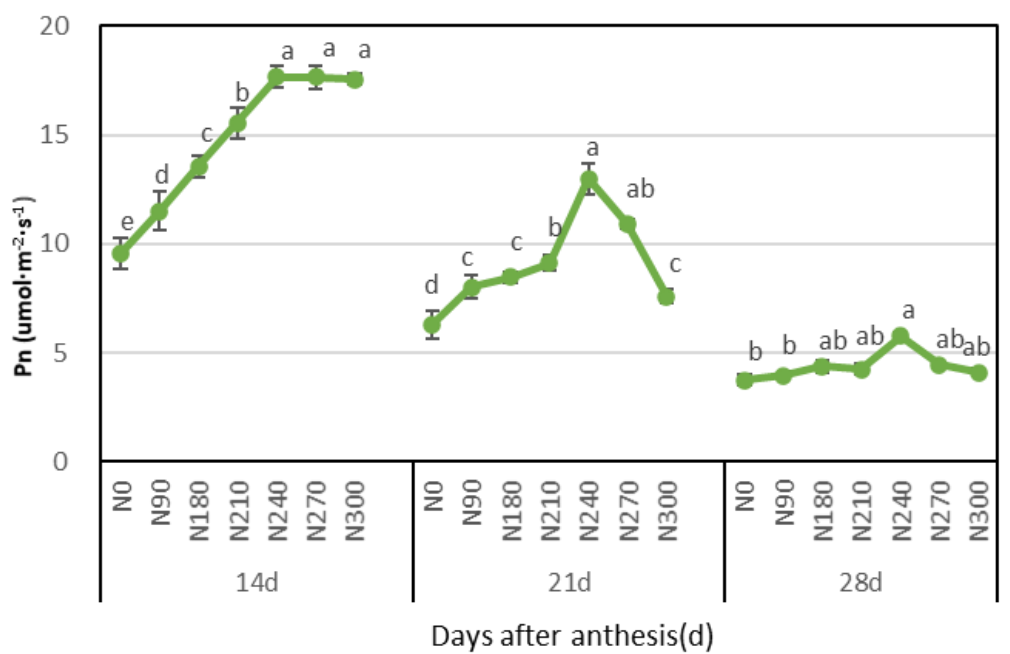

Figure 4. Effect of different sowing methods and nitrogen rate 14 Days, $21 \mathrm{D}$, and $28 \mathrm{D}$ after flowering on Net Photosynthesis Rate (Pn) of flag leaves Sowing technique2BMF-12/6, tillage, auto-fertilization WSS: wide space sowing; DS: 2BXF-12 Seed driller, Nonghaha company, notill, auto-fertilization drilling sowing; of winter wheat

\section{Effect of different sowing methods and nitrogen rates on intercellular carbon dioxide concentration (Ci) in flag after flowering}

The intercellular carbon dioxide concentration in the flag leaves of wide space sowing (WSS), drill sowing (DS) in wheat decreased gradually with the growing process and intercellular carbon dioxide concentration in the flag leaves decreased first and then increased with the increase of nitrogen application at different stages after flowering (Fig. 5). The $\mathrm{N}_{240}$ treatment was significantly lower than other treatments on 14 days and 21 days after flowering and $\mathrm{N}_{0}$ was the highest $\mathrm{N}_{240}$ and was the lowest 28 days after flowering, but the difference was not significant compared with $\mathrm{N}_{270}$. It can be seen that the increase of nitrogen fertilizer can significantly reduce the intercellular carbon dioxide concentration in the leaves of the flags after flower and the whole grouting period can be continued. 


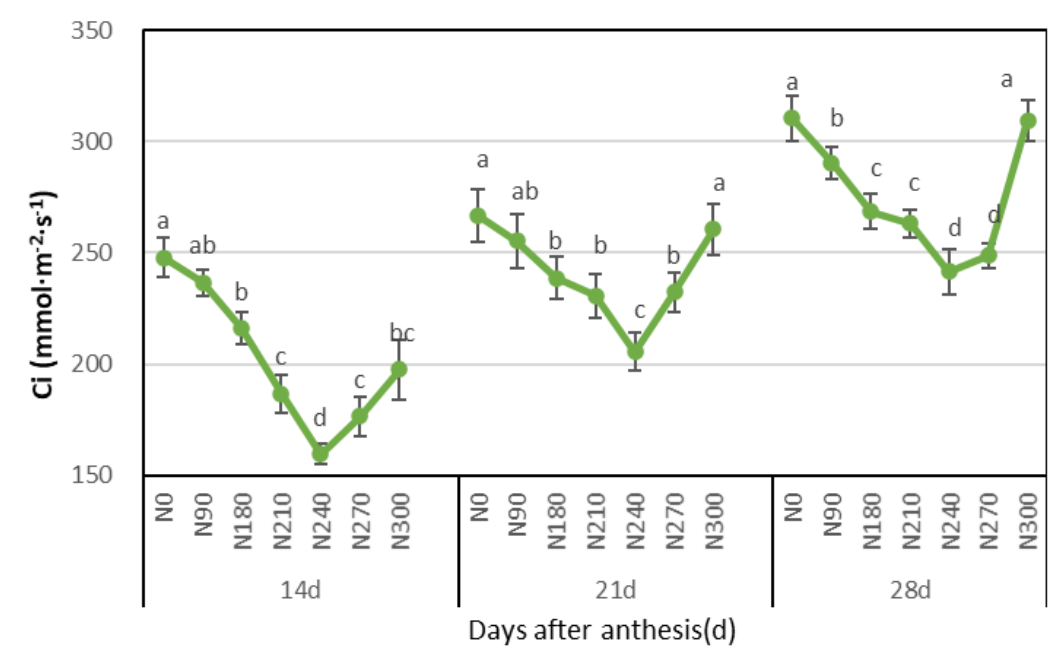

Figure 5. Effect of different sowing methods and nitrogen rate14 Days, 21 D, and 28 D after flowering on intercellular carbon dioxide concentration (Ci) of flag leaves Sowing technique2BMF-12/6, tillage, auto-fertilization WSS: wide space sowing; DS: 2BXF-12Seed driller, Nonghaha company, no-till, auto-fertilization drilling sowing; of winter wheat

\section{Effect of different sowing methods and nitrogen rates on stomatal conductance (Gs) of flag leaves after flowering}

The stomatal conductance of the flag leaves of wide space sowing (WSS) and drilling sowing (DS) wheat decreased gradually with the process of growing and the stomatal conductance of the flag leaves increased first and then decreased with the increase of nitrogen application at different stages after flowering (Fig. O). The $\mathrm{N}_{240}$ treatment was significantly higher than other treatments 14 days after flowering and $\mathrm{N}_{0}$, it was the lowest and $\mathrm{N}_{240}$ was the highest at 21-28 days, but the difference was not significant. It can be seen that increased nitrogen fertilizer can significantly increase stomatal conductance of flower flag leaves, but the effect lasts until the middle stage of growth and the effect weakened in the later stage.

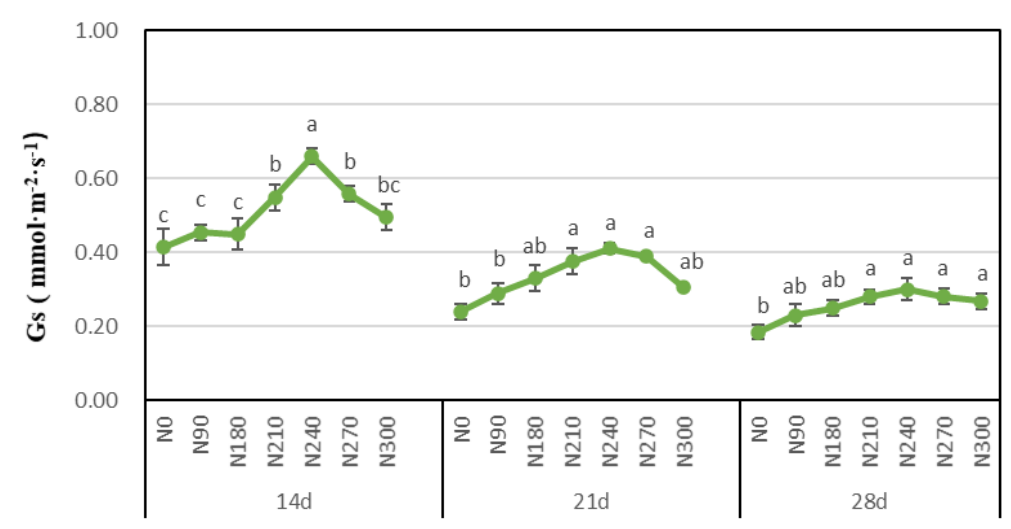

Days after anthesis(d)

Figure 6. Effect of different sowing methods and nitrogen rate 14 Days, $21 \mathrm{D}$, and $28 \mathrm{D}$ after flowering on stomatal conductance (GS) of flag leaves Sowing technique2BMF-12/6, tillage, auto-fertilization WSS: wide space sowing; DS: 2BXF-12 Seed driller, Nonghaha company, notill, auto-fertilization drilling sowing; of winter wheat 
Effect of different sowing methods and nitrogen rates on transpiration rate (Tr) of flag leaves after flowering

The transpiration rate of flag leaves decreased gradually with the grouting process and the transpiration rate of flag leaves increased first and then decreased with the increase of nitrogen application in different stages after flowering (Fig. 7). The $\mathrm{N}_{240}$ and $\mathrm{N}_{270}$ treatments were significantly higher than other treatments on 14 days and 21 days, after flowering and $\mathrm{N}_{0}$ was the lowest. After 28 days $\mathrm{N}_{240}$ was significantly higher than other treatments and $\mathrm{N}_{0}$ was the lowest. It can be seen that increased nitrogen fertilizer can significantly enhance the transpiration rate of flag leaves after flowering, which could last for the whole growth period and the best effect of $\mathrm{N}_{240}$ was obtained in the large WSS and DS.

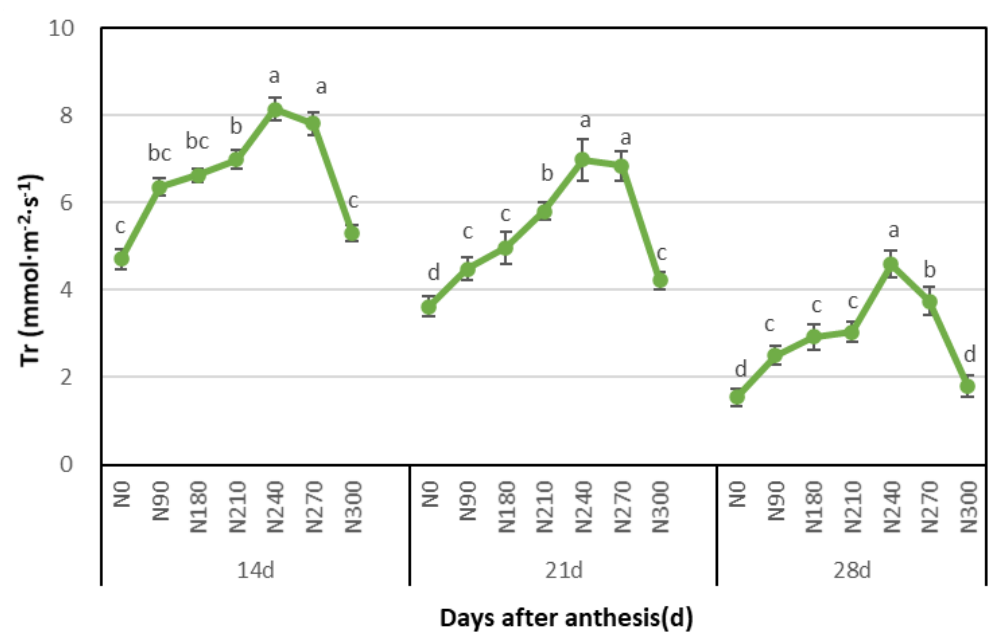

Figure 7. Effect of different sowing methods and nitrogen rate 14 Days, $21 D$ and $28 D$ after flowering on transpiration rate (TR) of flag leaves Sowing technique 2BMF-12/6, tillage, autofertilization WSS: wide space sowing; DS: 2BXF-12 Seed driller, Nonghaha company, no-till, auto-fertilization drilling sowing; of winter wheat

\section{Effect of different sowing methods and nitrogen rate on soluble sugar content, sucrose content and starch content of wheat grains}

The wide space sowing (WSS) method increased the soluble sugar content, sugar content and starch content in wheat grain during winter season when applied nitrogen at N300 and N270 respectively. Lowest soluble sugar content, sucrose content and starch content were count in the lower dose of nitrogen N90 and N190 as compare to control N0 and N300 (Table 6). The nitrogen application has a significant effect on soluble sugar content, sucrose content and starch content, but when nitrogen application given at certain level.

\section{Effect of different sowing methods and nitrogen content of soil at 0-200 cm during major fertility periods}

The nitrogen content of soil in different soil layers increased gradually with the increase of nitrogen application in different fertility periods and the N0 content was the lowest without the use of nitrogen treatment (Fig. 8). Compared between the nitrogen treatments there were no significant differences in the nitrogen content of soil in winter 
and no significant differences were found between the other soil layers. Among them the winter period 0-20 cm soil layer N300 was significantly higher than other nitrogen application treatment on 20-60 cm soil layer N270 and N300 were significantly higher than other treatments, $120 \mathrm{~cm}$ with N300 and N270 were the highest and compared with other nitrogen treatment differences significantly, maturity $0-120 \mathrm{~cm}$ soil nitrogen content with N300 significantly was higher than other nitrogen emissions treatment. $120-160 \mathrm{~cm}$ also with N300 was the highest but compared with other nitrogen treatment differences was not significant. The difference between treatments was deep as $160 \mathrm{~cm}$ in maturity, excessive nitrogen fertilizer was not conducive to wheat absorption of nitrogen. Wide space sowing (WWS) showed significant increase in the number of spikes, yield and an increase in the number of kernels per spike. For WS and DS, the yield and its three elements were the highest at $240 \mathrm{~kg} \cdot \mathrm{hm}^{-2}$ and $210 \mathrm{~kg} \cdot \mathrm{hm}^{-2}$, respectively. Therefore, wide space sowing (WWS) were equipped with $240 \mathrm{~kg} \cdot \mathrm{hm}^{-2}$ and regular strips were applied with $210 \mathrm{~kg} \cdot \mathrm{hm}^{-2}$ that achieved an increase in production.

Table 6. Effect of different sowing methods and nitrogen rate on soluble sugar content, sucrose content and starch content in grains winter

\begin{tabular}{c|c|c|c}
\hline $\mathbf{N}$ rate $\left(\mathbf{k g} \cdot \mathbf{h m}^{-2}\right)$ & Soluble sugar content\% & Sucrose content\% & Starch content \% \\
\hline $\mathrm{N}_{0}$ & $40.35_{\mathrm{c}}$ & $17.42_{\mathrm{b}}$ & $53.31_{\mathrm{c}}$ \\
$\mathrm{N}_{90}$ & $41.31_{\mathrm{c}}$ & $20.38_{\mathrm{b}}$ & $56.18 \mathrm{~b}_{\mathrm{c}}$ \\
$\mathrm{N}_{180}$ & $46.18_{\mathrm{bc}}$ & $22.82_{\mathrm{ab}}$ & $58.32_{\mathrm{b}}$ \\
$\mathrm{N}_{210}$ & $48.32_{\mathrm{b}}$ & $23.04_{\mathrm{a}}$ & $61.99_{\mathrm{b}}$ \\
$\mathrm{N}_{240}$ & $51.99_{\mathrm{b}}$ & $24.43_{\mathrm{a}}$ & $67.19_{\mathrm{a}}$ \\
$\mathrm{N}_{270}$ & $55.17_{\mathrm{a}}$ & $24.54_{\mathrm{a}}$ & $66.17_{\mathrm{a}}$ \\
$\mathrm{N}_{300}$ & $57.19_{\mathrm{a}}$ & $25.64_{\mathrm{a}}$ & $69.35_{\mathrm{a}}$ \\
\hline
\end{tabular}

\section{Effect of different sowing methods on plant nitrogen accumulation in main growth period}

The accumulation of plant nitrogen in wide space sowing (WSS) wheat growth process increased and increase of nitrogen application the accumulation of plant nitrogen showed a trend of increasing and then decreasing in each growth periods (Fig. 9). The nitrogen accumulation of wheat plant in different growth stages were the highest in $\mathrm{N}_{240}$ treatment and showed significant difference and it was the lowest in $\mathrm{N}_{0}$ treatment. It can be seen that $\mathrm{N}_{240}$ combined with wide space sowing can promote nitrogen accumulation in plants at all growth stages and provide nitrogen source for high yield. Wide space sowing (WSS) with the nitrogen of $240 \mathrm{~kg} \cdot \mathrm{hm}^{-2}$ could obtain nitrogen accumulation, which increased in all growth stages and the nitrogen accumulation and its proportion increased significantly during the wintering to jointing stage and proportion of nitrogen accumulation in the early growth period increased and the nitrogen accumulation of various organs increased, the nitrogen pre-anthesis nitrogen translocation amount and nitrogen accumulation amount after anthesis increased significantly, but Nitrogen uptake efficiency, nitrogen use efficiency and nitrogen productive efficiency were the highest at $90 \mathrm{~kg} \cdot \mathrm{hm}^{-2}$ and was the lowest at 300 $\mathrm{kg} \cdot \mathrm{hm}^{-2}$. 

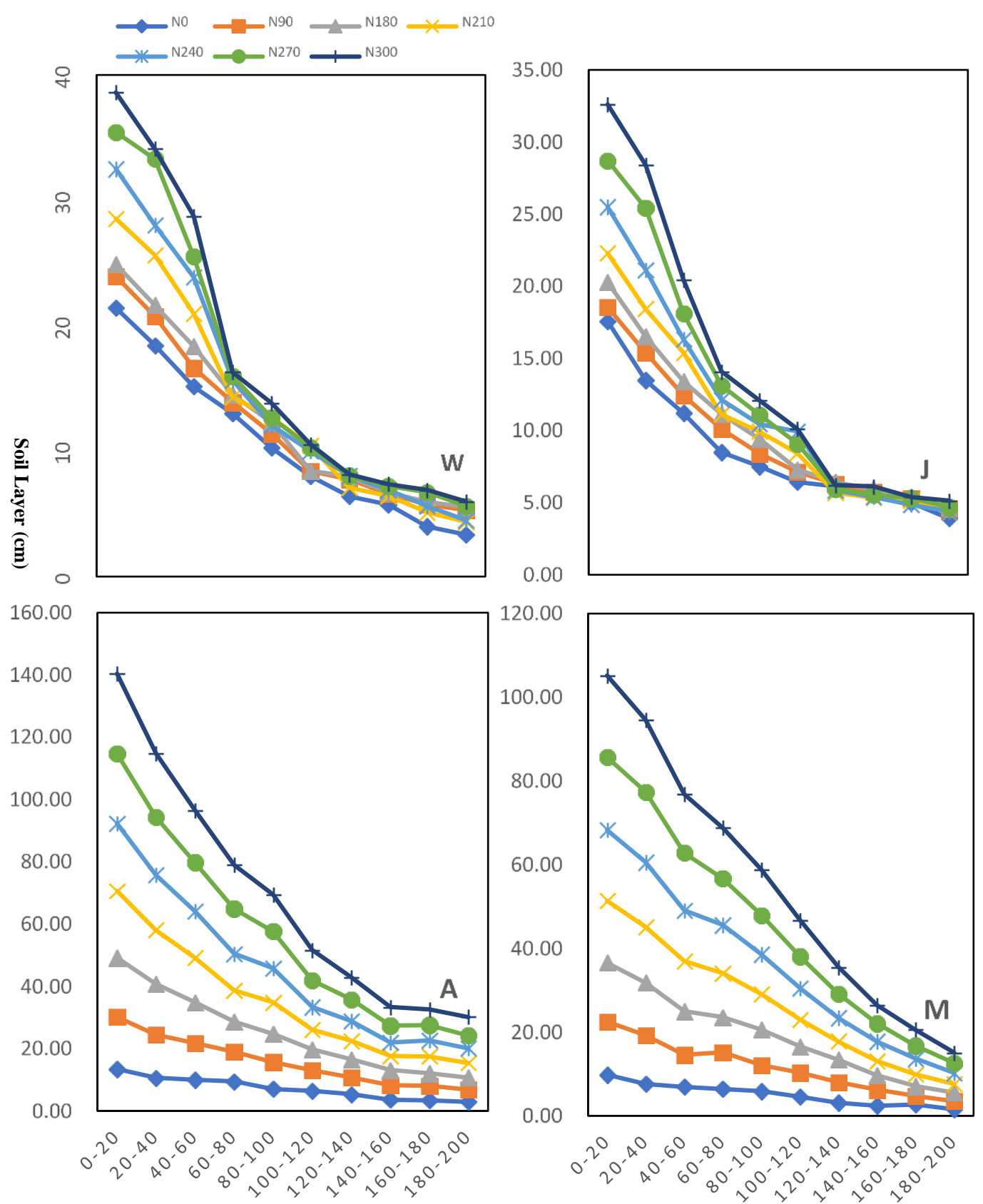

WSS-DS

Soil $\mathrm{NO}_{3}^{-}-\mathrm{N}$ content $\left(\mathrm{mg}^{-\mathrm{kg}^{-1}}\right.$, dry soil $)$

WSS-DS

Figure 8. Effect of different sowing methods and nitrogen rate on nitrate nitrogen content at 0 $200 \mathrm{~cm}$ soil layers of winter wheat at different growth stages of winter wheat. W, J, A, and M indicate wintering, jointing, anthesis, and maturity stages; WSS: wide space sowing; DS drilling sowing $W-J-A$ and M: 01 Oct to $30 \mathrm{Nov}$; W-J (wintering-jointing): 1 Dec to 25 Apr; J-A (jointing-anthesis): 26 Apr to 1 May; A-M (anthesis-maturity):2 May to 9 Jun, total growth period Sowing technique 2BMF-12/6, tillage, auto-fertilization WSS: wide space sowing; DS:

2BXF-12Seed driller, Nonghaha company, no-till, auto-fertilization drilling sowing 


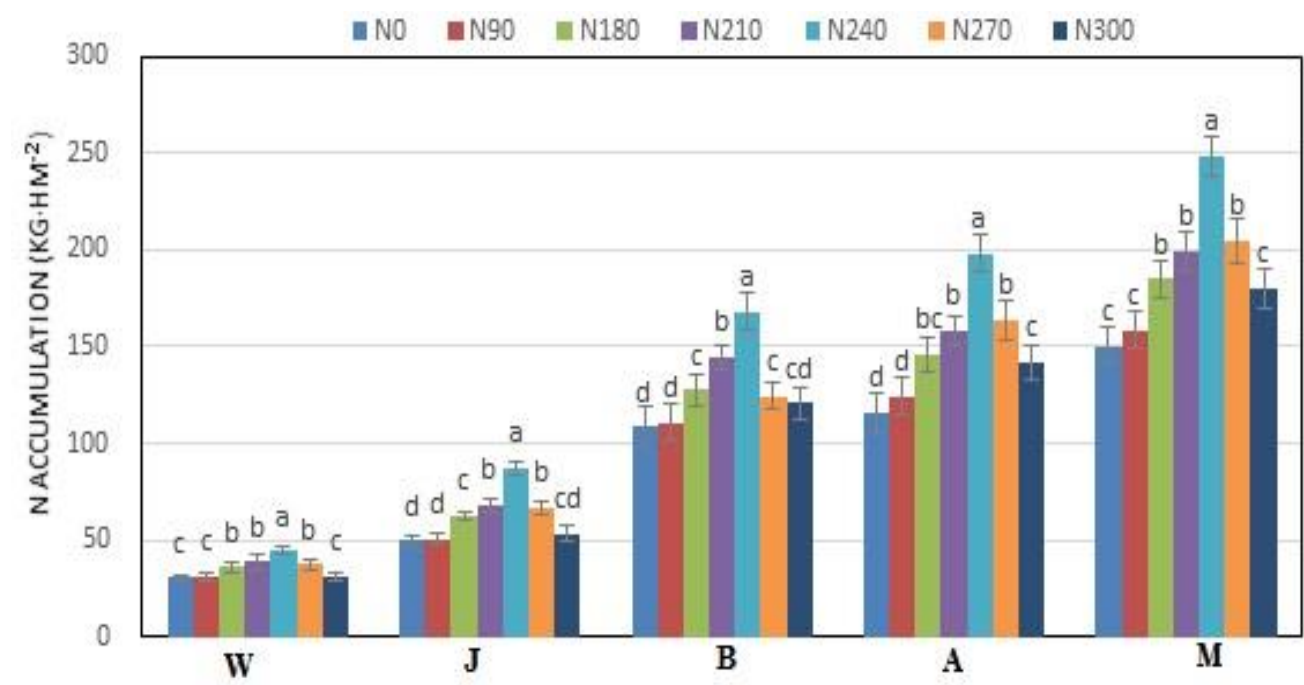

Figure 9. Effect of different sowing methods and nitrogen rate on nitrogen accumulation of winter wheat at different growth stages of winter wheat. $W, J, B, A$, and $M$ indicate wintering stage, jointing, bolting, anthesis, and maturity stages; (21 June - 30 September), sowing to wintering (1 October - 30 November), wintering to jointing (1 December T0 10 April) Jointing stage to Booting (11 April to 25 April), jointing to Anthesis (26 April - 1 May) and anthesis to maturity (2 May - 9 June) Sowing technique 2BMF-12/6, tillage, auto-fertilization WSS: wide space sowing; DS: 2BXF-12 Seed driller, Nonghaha company, no-till, auto-fertilization drilling sowing

\section{Correlation coefficients between water consumption and yield components at different growth stage in dryland wheat}

The results of the correlation analysis of total water consumption and yield in the growth period of wide space sowing wheat showed that total water consumption in the growth period was significantly positively correlated with yield $(\mathrm{P}<0.01)$. Further (Fig. 10), water consumption during growth period was closely related to yield.

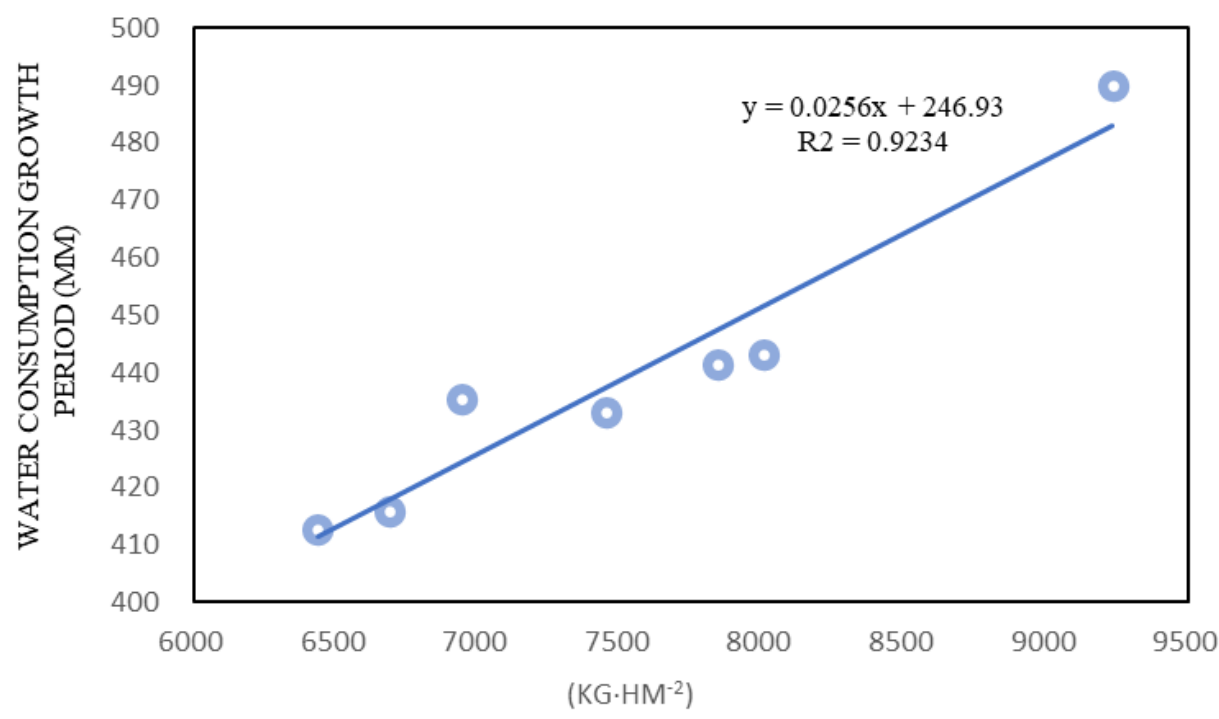

Figure 10. Correlation coefficients between water consumption and yield in winter wheat 


\section{Discussion}

Wheat production in this region are facing great challenges of a scant water supply and nutrient deficit. Due to the sparse and deep groundwater resources, rainfall is the sole water source for wheat production in the Loess Plateau, and it is limited (200$600 \mathrm{~mm}$ ) and unevenly distributed. Only 30\%-40\% of annual rainfall occurs during winter wheat growing season, whereas most of the rain falls between July and September, which is concurrent with the summer fallow between two growing seasons of winter wheat (Li et al., 2015). Wheat yield in semiarid dryland areas is highly affected by the variation in the amount and distribution of seasonal precipitation (Wang et al., 2015). Precipitation is an important meteorological factor which affects soil water content. In the Loess Plateau and other dryland areas, the soil water content at the time of sowing is important for early growth of wheat and highly dependent on the precipitation during fallow season of dryland wheat (Kang et al., 2002; Rossato et al., 2017).

\section{Effect of different sowing methods on nitrogen rates fertilizer group quality and yield formation}

Soil is the basic need for plant survival the exchange of nutrients, water and gas between soil and crops affects the growth and development of crops yields then regulates the formation of yield and quality (Triboi et al., 2002). The amount of fertilization is significantly positively correlated with crop yields, so farmers pursue high yields by applying a large amount of fertilizer resulting in excessive nitrogen being dispersed in the air, water and soil causing a series of environmental and human health problems (Seong et al., 2018). The supply of nutrients in farmland is determined by the input of soil base fertility and fertilizers and the soil nutrient supply capacity and characteristics are different under different soil fertility, resulting in different characteristics of crop nutrients absorption and utilization which directly affects the utilization of nutrients (Matzen et al., 2019). The average output of WSS homogenous treatment is $8976 \mathrm{~kg} \mathrm{hm}^{-2}$ compared to the DS. Relatively coordinated to promote the production composition of the three factors of growth, so as to achieve a higher production than traditional strip production (Chen et al., 2016); Dang et al., 2015). However Han et al. (2013) showed that after the use of wide, the number of spikes significantly increased but the grain weight also increased and spike but did not reach the difference level and finally achieved increased production. According to Wei et al. (2016), from the wheat growth situation under different sowing methods the difference in the number of basic seedlings winter and spring equinox between the treatments was not significant indicating that the different sowing methods had a small impact on wheat sowing and seeding and the ability of wheat sowing planted in WSS was similar to that of ordinary strips. According to Anxia et al. (2015), due to the variety difference the effect of nitrogen fertilizer on tiller number in each growth stage of wheat population is different. The growth and development characteristics of different varieties appropriate amount of nitrogen fertilizer application and top dressing time are selected to achieve reasonable control of tiller number in each growth stage of wheat population. The results of this study showed that the application of $240 \mathrm{~kg} \mathrm{hm}^{-2}$ in wide and drilling significantly increased tillers in the jointing stage and the booting stage compared with other nitrogen treatments while there were no significant changes in other growth stages (Guo et al., 2016). Nitrogen application was beneficial to the ears development of 
wheat, increased the number of effective ears and grains per ear and achieved an increase in yield. However, excessive nitrogen application would reduce the total number of ears and 1000 grain weight of winter wheat leading to a decrease in yield. In a study of Ye et al. (2010), the three elements of wheat yield increased with the increase of nitrogen fertilizer amount, especially the 1000 grain weight and grain number per panicle reached significant levels. However, when nitrogen fertilizer amount exceeded $90 \mathrm{~kg} \cdot \mathrm{hm}^{-2}$, grain number per panicle could not reach a significant level and when nitrogen fertilizer amount increased to $180 \mathrm{~kg} \cdot \mathrm{hm}^{-2}$ or even $210 \mathrm{~kg} \cdot \mathrm{hm}^{-2}, 1000$ grain weight could not reach a significant level. According to Yang et al. (2018), increase of nitrogen application, the output and yield composition of the three factors will not show a single peak increase trend but show the first increase and then decrease trend in the nitrogen application of $180 \mathrm{~kg} \mathrm{hm}^{-2}$, the number of grain weight and spike reached the maximum at $240 \mathrm{~kg} \mathrm{hm}^{-2}$. The number of spike particles and yield were maximized and the differences were significant. The results of this experiment showed that with the increase of nitrogen application, the number of spikes, spike grains and thousands of grain weight, the yield increases first and then it decreases, the spike number and yield difference was significant but the difference between the number of spike and thousands of grains was not significant and the DS cast $210 \mathrm{~kg}$. The number of $\mathrm{h}^{-2}$ spike particles and yield increased significantly and there was no significant difference between the number of spikes and the weight of thousands which showed that on the basis of the seeding method affecting the yield composition wide space sowing (WSS) was a stronger nitrogen fertilizer utilization capacity which was more consistent with the previous studies.

\section{Effect of different sowing methods on nitrogen rates fertilizer and water utilization}

Currently advocated water saving agriculture is faced with such problems as how to improve soil water utilization efficiency, reduce ineffective water consumption and strengthen wheat's utilization of water in deep soil. In addition to improving varieties adjusting crop layout and cultivation mode is a low cost efficient and fast way. The ability of wheat to adapt to changing conditions in the process of growing depends not only on the genetic characteristics of the variety itself but also on the farmland microenvironment due to changing planting patterns. The planting mode is a factor that can be controlled in agricultural production, water and nitrogen utilization efficiency is determined by multiple factors and all factors that can affect grain yield water consumption and nitrogen will directly or indirectly affect water utilization efficiency (Maaiping et al., 2009). One of a research work shows that the drilling spacing in order to reduce the basic seedlings and establish reasonable population quality can be optimized after flowering plant physiological characteristics increase capacity, improve the grain-filling ability but small planting distance contributed to the growing contradiction between individual body, poor resource utilization condition of field in the field. Therefore, by increasing the row space and width appropriately, the sowing quality can be improved the reasonable group structure can be constructed and the individual growing environment can be improved. The experimental study of Crisálida et al. (2018) shows that the wide drilling with $240 \mathrm{~kg} \cdot \mathrm{hm}^{-2}$ reduce the proportion of rainfall and irrigation water consumption, water consumption and soil water storage and its proportion increase may be due to wide drilling soil root spatial distribution promoted the root soil water use of water. The results of this study also showed that the water consumption of seeding jointing and jointing flowering increased with the 
adoption of WSS compared with the DS. Moreover, the total water consumption during the growth period of wide and drill was significantly positively correlated with the yield $(\mathrm{P}<0.01)$. The drill also showed a positive correlation but not significantly. However, research conducted by Wang et al. (2013) showed that wide sowing made the inter-row plant spacing more evenly distributed. However, as the row spacing became wider the wheat population was not evenly distributed on the whole and the land cover was not complete. According to the study of Zhou et al. (2008), nitrogen application had a regulatory effect on water consumption indexes in different growth stages. Water consumption in the early stage of nitrogen application and water consumption model coefficient in the late stage of growth promoted the use of soil water and nitrogen by roots and the growth of vegetative organs. Appropriate application can improve the utilization ability of wheat to soil water storage reduce the dependence on natural precipitation and irrigation and compensate for the impact of insufficient irrigation on grain yield (Ercoli et al., 2008; Yan et al., 2012). Research showed that nitrogen fertilizer had a greater effect on water consumption in the stage and increased nitrogen fertilizer application could increase water consumption in the stage of greeningflowering and its proportion, so that the peak of water consumption moved forward. The results of this study showed that with the increase of nitrogen application, the water consumption in the early and middle stages of growth and their proportion, as well as the water consumption in the jointing flowering stage first increased and then decreased and the water consumption in the later stages first decreased and then increased. Among them the wide drilling with $240 \mathrm{~kg} \mathrm{hm}^{-2}$ improved planting jointing stage and jointing stage, flowering two stage water consumption and its proportion reduced, According to Shi et al. (2008), total water consumption during the growth period of nitrogen treatment was significantly higher than that of non-nitrogen treatment. Compared with nitrogen application, the total water consumption of $210 \mathrm{~kg} \mathrm{hm}^{-2}$ treatment the proportion of irrigation water and the water consumption of soil storage were the highest. Compared with other treatments the difference was significant indicating that the suitable nitrogen application of $210 \mathrm{~kg} \mathrm{hm}^{-2}$ in this area promoted the utilization of soil water storage by wheat. The results of this study showed that with the increase of nitrogen application the water consumption of soil storage water and its proportion first increased and then decreased. The proportion of precipitation and irrigation water consumption of $240 \mathrm{~kg} \mathrm{hm}^{-2}$ combined with wide drilling was the lowest, while the proportion of water consumption of soil storage water and its proportion were the highest. In terms of sowing characteristics wide drilling has the growth conditions to make full use of water and the coordination between water and nutrients was very important for the growth and development of crops. The utilization of soil water in wheat fields will directly affect the efficiency of nitrogen fertilizers. The studies also showed that within the scope of $0-360 \mathrm{~kg} \mathrm{hm}^{-2} \mathrm{~N} 240 \mathrm{~kg} \mathrm{hm}^{-2}$ more than $180 \mathrm{~kg} \mathrm{hm}^{-2}$ was the most appropriate nitrogen treatment. Nitrogen treatment increased by $9.53 \%$, but the utilization efficiency of precipitation and water use efficiency increased by $9.54 \%$ and $21.04 \%$, respectively (Wang et al., 2012).

\section{Effect of different sowing methods and nitrogen fertilizer on photosynthesis characteristics of post-flower flag leaves}

Photosynthetic rate, stomatal conductance, transpiration rate and chlorophyll content are important components of photosynthetic physiological characteristics of crops. Nitrogen is the main element of protein synthesis an important component of grain 
closely related to the life activities of crops and an indispensable nutrient limiting factor in agricultural production. As a result, nitrogen has been applied extensively in agricultural production over the past few decades to increase wheat yields. However, some studies have shown that under the condition of high nitrogen application the photosynthetic rate of leaves decreased and with the application of a large amount of nitrogen fertilizer in agricultural production the loss of fertilizer was directly caused and soil pollution was serious and the agricultural ecological environment entered a vicious circle. Wang et al. (2012) showed that the light transmittance of the large WSS and DS wheat population was significantly better than that of the traditional row spacing sowing wheat which could significantly adjust the net photosynthetic characteristics of the flower flag leaves. The results of this study showed that broad drilling with $240 \mathrm{~kg} \mathrm{hm}^{-2}$ improved the photosynthetic characteristics of flag leaves, significantly increased the net photosynthetic rate, stomatal conductance and transpiration rate of flag leaves after flowering and significantly reduced the intercellular carbon dioxide concentration. This may be due to that the wide precision sowing expanded the width and row spacing, optimized the light conditions for the population in the field and at the same time, the suitable nitrogen application made reasonable use of the photo thermal resources. The nutrient conditions were good the individual plants developed well the green leaf area was large, function time was long and aging time of the whole plant in the later stage of wheat was delayed, so as to avoid the early aging of the leaves (Hu et al., 2016). Study showed that leaf photosynthesis was closely related to crop yield and leaf photosynthetic rate was an important reason for crop high yield while nitrogen fertilizer could enhance plants' ability to synthesize chlorophyll and was one of the most effective factors to regulate plant leaf photosynthetic capacity (Li et al., 2010; Fuentes et al., 2003). Their research experience define that when the soil water content was the same the Pn of wheat generally increased first and then became stable with the increase of nitrogen application and the intercellular carbon dioxide concentration transpiration rate and net photosynthetic rate generally increased first and then decreased, which also indicated that appropriate nitrogen application is beneficial for improving the photosynthetic capacity of wheat flag leaves during the filling period. Appropriate nitrogen application is also expected to improve the photosynthetic capacity of winter wheat over ground parts increase the accumulation and transfer of dry matter and promote the increase of wheat yield. The results of this study showed that the photosynthetic indexes in the flag leaves of the broad drilling with 240 $\mathrm{kg} \cdot \mathrm{hm}^{-2}$ fertilizer all reached the optimal level which may be due to the appropriate nitrogen fertilizer amount promoting the synthesis of chlorophyll. In addition, the protective enzyme activity level in the wheat plant was maintained at the same time. However, some studies have shown that increased nitrogen fertilizer is beneficial to increase the population leaf area of wheat and optimize the canopy environment. However, excessive nitrogen fertilizer will reduce leaf inclination and excessive leaf area will lead to unreasonable canopy structure resulting in wheat yield loss (Song et al., 2016).

\section{Effect of different sowing methods and nitrogen fertilizer on nitrogen metabolism}

Increasing the amount of nitrogen fertilizer can increase the effective nitrogen content of wheat field tillage layer and promote nitrogen absorption in wheat plants. Nitrogen emissions ranged from $120 \mathrm{~kg} \mathrm{hm}^{-2}$ to $240 \mathrm{~kg} \mathrm{hm}^{-2}$ increasing the accumulation of nitrogen in various organs during maturation but reducing the transfer rate of nitrogen accumulation to grain in the organs after flowering. According to Zhang 
et al. (2012), due to the increase in nitrogen application wheat organs before the operation of nitrogen and the accumulation of nitrogen in the mature period increased but the nutrient organs before the accumulation of nitrogen operation rate and the contribution rate of nitrogen to grain after flowering did not change significantly. The results of this study also show that the amount of nitrogen running before flowering increases and then decreases after the increase of nitrogen accumulation before flowering the contribution rate of nitrogen operation to grain before flowering also increases and then decreases but not significantly. The reason for the analysis may be that water fertilizer needs to be increased synchronously with increasing the amount of nitrogen applied but the lack of water in wheat fields cannot make full use of nitrogen fertilizer but is not conducive to the operation and accumulation of nitrogen in the plant (Chai et al., 2010; Guo et al., 2018). Work shows that nitrogen fertilizer recycling rate, nitrogen fertilizer agronomy efficiency nitrogen fertilizer production efficiency and nitrogen fertilizer utilization efficiency show a decreasing trend with the increase of nitrogen application when nitrogen application exceeds $240 \mathrm{~kg} \mathrm{hm}^{-2}$ soil nitrogen content increases and with the extension of planting age this is more obvious. This study shows that nitrogen absorption efficiency nitrogen utilization efficiency and nitrogen production efficiency were all $90 \mathrm{~kg} \mathrm{hm}^{-2}$, soil nitrogen content with the increase of nitrogen yield and soil layer deepening, the difference between treatment can be as deep as $160 \mathrm{~cm}$ in maturity, Excessive application of nitrogen fertilizer was not conducive to the absorption of nitrogen in wheat, which was more consistent with previous studies.

\section{Effect of different sowing methods and nitrogen rates fertilizer on grain quality}

In recent years with the reform of agricultural structure wheat production is changing from high yield to green age. The arrival of the green era not only means the strategy of weight loss and drug reduction, the pursuit of high quality wheat, the establishment of reasonable quality evaluation standards are the most urgent tasks and in the current regulation of wheat quality of many factors nitrogen fertilizer regulation is the most effective measure (Wang et al., 2015). The total protein content and component content of wheat grains of different grains increased significantly with the increase of nitrogen application. The analysis of the proportion of each protein component of wheat grain to the total protein in this experiment showed that the protein component content increased, the protein was the highest at $240 \mathrm{~kg}, \mathrm{hm}^{-2}$ the globulin was the highest at $270 \mathrm{~kg} \mathrm{hm}^{-2}$ and the alcohol soluble protein and wheat gluten (storage protein) were the highest at $300 \mathrm{~kg} \mathrm{hm}^{-2}$. The globulin ratio was the highest at $\mathrm{N} 240$ the protein content were $300 \mathrm{~kg} \mathrm{hm}^{-2}, 240 \mathrm{~kg} \mathrm{hm}^{-2}$ and the protein yield was $240 \mathrm{~kg} \mathrm{hm}^{-2}$ significantly higher than that of other nitrogen treatment. The study also found that clear protein and globulin were more regulated by nitrogen fertilizer in the grout stage, while alcohol soluble protein and wheat gluten were more sensitive to nitrogen fertilizer reaction in the later stage of grouting. However, there were also reports that with the increase of nitrogen application the increase in seed globulin and alcohol-soluble protein can be observed, while the content of clear protein and gluten has a tendency to decrease (Fuentes et al., 2003). Analysis of the reasons resulted in the consequence that varieties were the main factors affecting quality in addition according to Wang et al. (2016), that different soil fertility protein components to nitrogen application level are not the same. At the same time, it is shown that the response of strong middle and weak wheat to nitrogen fertilizer is very different. The application of the appropriate amount of nitrogen fertilizer is conducive to improving the nutritional quality of wheat and 
processing quality. Nitrogen application in the range of $0-300 \mathrm{~kg} \mathrm{hm}^{-2}$ nitrogen and wheat actual yield and protein yield of the secondary curve relationship was conducive to improve protein, wet gluten content and sedimentation value and other indicators at the same time can extend the formation time and stability time of the dough (Cao et al., 2005). The results show that with the increase of nitrogen fertilizer, the sedimentation value, landing value and formation time, stabilization time, wet gluten and gluten index increased but the water absorption rate were relatively stable, which is consistent with the previous research results.

\section{Conclusions}

The number of spikes and production increased significantly the number of spike particles also increased. DS can optimize the output of the three elements at the same time. Further analysis shows that the wide space sowing was distributed with $240 \mathrm{~kg} \mathrm{hm}^{-2}$ to reduce precipitation and irrigation increased the water consumption and proportion of soil water storage increased the water consumption in the sowing extraction and extraction flowering stages and ultimately increased the total water consumption during fertility and improved the efficiency of water utilization at the same time, reduced the high yield of each organ, increased the dry quality of each organ, increased the dry quality of the plant in the extraction-flowering and flowering maturity stage and its proportion increased the grain weight of each time after flowering, the number of spikes and yield increased significantly. The pore conductivity and steaming rate reduced the concentration of carbon dioxide between cells resulting in high yield. In addition, WSS distribution with $240 \mathrm{~kg} \mathrm{hm}^{-2}$ to increase the accumulation of nitrogen in plants during the main fertility period significantly increased the accumulation of nitrogen in each stage of fertility the proportion of nitrogen accumulation increased in the pre fertility stage and the accumulation of nitrogen increased in various organs during maturity, the amount of nitrogen before flowering and nitrogen accumulation after flowering significantly increased, while ensuring the yield. It was beneficial for the improvement of sugar and protein content and the quality of wheat.

Acknowledgements. "Modern Agriculture Industry Technology System Construction” (No. CARS-3-124); The National Key Research and Development Program of China (No. 2018YFD020040105); The Sanjin Scholar Support Special Funds Projects; National Natural Science Foundation of China (No. 31771727); The "1331" Engineering Key Innovation Cultivation Team-Organic Dry Cultivation and Cultivation Physiology Innovation Team (No. SXYBKY201733).

\section{REFERENCES}

[1] Ahmad, W., Shah, Z., Khan, F., Ali, S., Malik, W. et al. (2013): Maize yield and soil properties as influenced by integrated use of organic, inorganic and bio-fertilizers in a low fertility soil. - Soil Environ. 32: 121-129.

[2] Anxia, Z. H., Jiang, F. et al. (2015): Effects of nitrogen fertilizer amount on population dynamics and yield of different varieties of wheat. - China Seed Industry 12: 65-67.

[3] Bayhan, Y., Kayışoğlu, B., Gönülol, E., Yalçın, H., Sungur, N. (2006); Possibilities of direct drilling and reduced tillage in second crop silage corn. - Soil and Tillage Research 88: $1-7$. 
[4] Bergeron, T. et al. (1949): The problem of artificial control of rainfall on the globe. I. General effects of ice-nuclei in clouds. - Tellus 1: $32^{\wedge} 13$.

[5] Black, A. L., Siddoway, F. H. et al. (1977): Winter wheat recropping on dryland as affected by stubble height and nitrogen fertilization. - Soil Sci. Soc. Am. J. 41: 11861190.

[6] Cao, C. F., Kong, L. C., Wang, J. L. et al. (2005): Effects of nitrogen application on yield, quality and nutrient absorption of wheat with strong and medium gluten. - Plant Nutrition and Fertilizer 1: 46-50.

[7] Chai, Y. J., Xiong, Y. S., et al. (2010): Effects of nitrogen application on nitrogen accumulation and operation of different winter wheat varieties. - Acta Botanica Sinica Northwestern 30(10): 2040-2046.

[8] Chen, C., Fan, S., Liu, G. et al. (2016): Comparison of yield and agronomic traits of spring wheat with wide-spread spread sowing and conventional strip-sowing. - Gansu Agricultural Science and Technology 1: 36-38.

[9] Crisálida, M. V., Coelho, K. P., Luz, T. R. S. A. et al. (2018): Effect of different water application rates and nitrogen fertilization on growth and essential oil of clove basil. Industrial Crops \& Products 125.

[10] Dang, W., Ma, C., Zhao, Q., Feng, Z. H. et al. (2015): Effects of wide precision sowing on wheat yield and yield components. - Hebei Agricultural Sciences 19(2): 15-17.

[11] Encyclopedia Britannica (2013): Loess Plateau. - Encyclopedia Britannica, Inc., Chicago.

[12] Ercoli, L., Lulli, L., Mariotti, M. (2008): Post-anthesis dry matter and nitrogen dynamics in durum wheat as affected by nitrogen supply and soil water availability. - European Journal of Agronomy 28(2): 138-147.

[13] Fuentes, P. J., Flury, M., Huggins, R. D. et al. (2003): Soil water and nitrogen dynamics in dryland cropping systems of Washington State, USA. - Soil and Tillage Research 71: 33-47.

[14] Gonzalez-Dugo, V., Durand, J. L., Gastal, F. (2010): Water deficit and nitrogen nutrition of crops. A review. - Agron. Sustain. Dev. 30: 529-544.

[15] Guo, L., Shi, J.-S., Wang, L.-Y. et al. (2018): Effects of nitrogen application on nitrogen uptake and utilization and soil nitrate nitrogen content in summer maize under integrated drip irrigation with water and fertilizer. - Chinese Journal of Ecological Agriculture 26(5): 668-676.

[16] Guo, M., Zhao, G., Guo, W. et al. (2016): Effects of nitrogen application and row spacing on winter wheat yield and physiological characteristics. - Journal of Nuclear Agriculture 30(4): 805-812.

[17] Han, H. F., Zhao, D. D., Shen, J. Y. et al. (2013); Effects of irrigation amount and period on yield and quality characteristics of large-area precision winter wheat. - Chinese Journal of Agricultural Engineering 29(14): 109-114.

[18] Horvat, D., Jurkovic, Z., Drezner, G., Simic, G., Novoselovic, D., Dvojkovic, K. et al. (2006); the influence of gluten proteins on technological properties of Croatian wheat cultivars. - Cereal Res. Commun. 34: 1177-1184.

[19] Hu, M. Y., Menf, Y., Zhang, Y. J., (2016); Research progress on the effects of water and nitrogen interaction on crop physiological characteristics and nitrogen utilization. Journal of Wheat Crops 36(3): 332-340.

[20] Kang, S., Zhang, L., Liang, Y., Dawes, W. R. (2002); Simulation of Winter Wheat Yield and Water Use Efficiency on the Loess Plateau of China Using WAVES. - In: McVicar, T. R., Rui, L., Walker, J., Fitzpatrick, R. W., Changming, L. (eds.) Regional Water and Soil Assessment for Managing Sustainable Agriculture in China and Australia. ACIAR Monograph No. 84. Australian Centre for International Agricultural Research, Bruce, pp. 95-104.

[21] Li, H., Xue, J.-F., Gao, Z. -Q., Xue, N.-W., Yang, Z. -P et al. (2018); Response of yield increase for dryland winter wheat to tillage practice during summer fallow and sowing method in the Loess Plateau of China. - J. Integr. Agric. 17: 817-825. 
[22] Li, J., Yao, Y., Ding, Z. et al. (2010); Effects of furrow sowing on dry matter, soil water use efficiency and soil temperature of winter wheat populations. - Crop Research 24(1): 16-18.

[23] Li, N. N., Sun, M., Gao, Z. Q. et al. (2018); Study on the relationship between water consumption of deep pine and mulch seeding in upland wheat fields with extreme annual pattern and nitrogen uptake and utilization in plants. - Sci Agric Sinica 51(18): 34553469 .

[24] Li, S. X. et al. (2002): Ways and strategies for increasing fertilizer nitrogen efficiency in dryland soil. - Acta Pedologica Sinica 39(Suppl.): 56-75.

[25] Li, S., Xiao, L. (1992); Distribution and management of drylands in the People's Republic of China. - Advances in Soil Science 18: 148-293.

[26] Li, Z., Feng, W. et al. (2015); Effects of sow spacing on water consumption characteristics of winter wheat. - Henan Agricultural Science 44(2): 22-27.

[27] Liang, Y. F., Khan, S., Ren, A. X., Lin, W., Anwar, S., Sun, M., Gao, Z. Q. (2019): Subsoiling and sowing time influence soil water content, nitrogen translocation and yield of dryland winter wheat. - Agronomy 9(1): 37.

[28] Liu, J. H., Dang, Z. P., Cao, W. X., Ai-Ping, Y. U. et al. (2005): Effect of different mulching and sowing methods on wheat yield and soil water content in Weibei. - The Journal of Applied Ecology 21(2): 351-358.

[29] Lu, D. J., Lu, F. F., Yan, P., Cui, Z. L., Chen, X. P. et al. (2014); Elucidating population establishment associated with $\mathrm{N}$ management and cultivars for wheat production in China. - Field Crops Research 163(1): 8189.

[30] Lu, D. J., Lu, F. F., Pan, J. X., Cui, Z. L., Zou, C. Q., Chen, X. P., He, M. R., Wang, Z. L. et al. (2015): The effects of cultivar and nitrogen management on wheat yield and nitrogen use efficiency in North China Plain. - Field Crops Research 171: 157-164.

[31] Ma, A., Wang, J., Jing, H. et al. (2009); Effects of different sowing row spacing and density on wheat yield and water use efficiency. - Shaanxi Agricultural Sciences 55(1): 3-5.

[32] Ma, W. Q., Zhang, F. S., Zhang, W. F. et al. (2005): Fertilizer production and consumption and the resources, environment, food security and sustainable development in China. - Resource Science 27(3): 33-40.

[33] Mann, C., Lynch, D., Fillmore, S., Mills, A. et al. (2019); Relationships between field management, soil health, and microbial community composition. - Appl. Soil Ecol. 144: 12-21. DOI: 10.1016/j.apsoil.06.012.

[34] Mao, Y., Lei, B., Chen, A. et al. (2015); Effects of different no-till mulch cultivation models on the adaptation of Yunnan spring potato to seasonal drought. - Soil Bulletin 46(3): 556-561.

[35] Matzen, N., Jørgensen, J. R., Holst, N. et al. (2019); Grain quality in wheat impact of disease management. - European Journal of Agronomy 103.

[36] Meng, Q. F., Yue, S. C., Hou, P., Cui, Z. L., Chen, X. P. et al. (2016); Improving yield and nitrogen use efficiency simultaneously for maize and wheat in China: a review. Pedosphere 26(2): 137-147.

[37] Pepó, P., Sipos, P., Gyõri, Z. et al. (2005); Effects of fertilizer application on the baking quality of winter wheat varieties in a long term experiment under continental climatic conditions in Hungary. - Cereal Res. Commun. 33: 825-832.

[38] Roelcke, M. et al. (1994); Die Ammoniak-Volatilisation nach Ausbringung von Mineraldünger-Stickstoff in carbonatreichen chinesischen Löss-Ackerböden. - PhD Dissertation, Technische Universität Braunschweig. Published in: Göttinger Beiträge zur Land- und Forstwirtschaft in den Tropen und Subtropen, Volume 92. Verlag Erich Goltze, Göttingen.

[39] Rossato, L., Alvalá, R. C., Marengo, J. A., Zeri, M., Cunha, A. P., Pires, L., Barbosa, H. A. (2017); Impact of soil moisture on crop yields over Brazilian semiarid. - Frontiers in Environmental Science 5: 73. 
[40] Seong-Woo, C., Chon-Sik, K., Hyeon, S. et al. (2018): Influence of protein characteristics and the proportion of gluten on end-use quality in Korean wheat cultivars. - Journal of Integrative Agriculture 17(8).

[41] Shi, X. K., Shi, Y., Zhao, J. Y. et al. (2008): Effects of nitrogen application on water consumption characteristics and grain yield of ultra-high-yield wheat variety yanong 1212. - Shandong Agricultural Sciences 50(5): 72-75.

[42] Song, M., Li, Z., Feng, H. et al. (2016); Characteristics of dry matter accumulation and yield effect of winter wheat at different water and nitrogen levels. - Chinese Journal of Agricultural Engineering 32(2): 119-126.

[43] Sun, M., Ge, X. M., Gao, Z. Q., Ren, A. X., Deng, Y., Zhao, W. F., Zhao, H. M. et al. (2014): Relationship between water storage conservation in fallow period and grains protein formation in dryland wheat in different precipitation years. - Scientia Agriculture since 47(9): 1692-1704 (in Chinese).

[44] Sun, M., Deng, Y., Gao, Z. Q., Zhao, H. M., Ren, A. X., Li, G. et al. (2015): Effects of tillage in fallow period and sowing methods on water storage and grain protein accumulation of dryland wheat. - Pakistan J. Agric. Sci. 52: 1-8.

[45] Sun, M., Ren, A. X., Gao, Z. Q., Wang, P. R., Mo, F., Xue, L. Z., Lei, M. M. et al. (2018): Long-term evaluation of tillage methods in fallow season for soil water storage, wheat yield and water use efficiency in semiarid southeast of the Loess Plateau. - Field Crops Res. 218: 24-32.

[46] Tao, Z., Wang, D., Ma, S., Yang, Y., Zhao, G., Chang, X. (2018): Light interception and radiation use efficiency response to tridimensional uniform sowing in winter wheat. $-\mathrm{J}$. Integr. Agric. 17 566-578.

[47] Tavakkoli, A. R., Oweis, T. Y. et al. (2004): The role of supplemental irrigation and nitrogen in producing bread wheat in the highlands of Iran. - Agro. Water Manage. 65: 225-236.

[48] Tribo1, E., Tribo1 Blondel, A. M. et al. (2002): Productivity and grain or seed composition: a new approach to an old problem: invited paper. - Eur J Agro 16: 163-186.

[49] Wang, C. Y., Dai, X. L., Shi, Y. H. et al. (2012): Study on the relationship between leaf area index and photosynthesis and yield of post-flowering wheat. - Chinese Journal of Plant Nutrition and Fertilizer 18(1): 27-34.

[50] Wang, H., Yu, Z., Zhang, Y., Shi, Y., Wang, D. et al. (2012): Effects of Tillage Regimes on Water Consumption and Dry Matter Accumulation in Dryland Wheat. - Acta Agron. Sin. 38: 675-682.

[51] Wang, L. F., Shangguan, Z. P. (2015): Water-use efficiency of dryland wheat in response to mulching and tillage practices on the Loess Plateau. - Scientific Reports 5: 12225.

[52] Wang, M., Zhao, G. C., Shi, S. B. et al. (2015): Effects of nitrogen application on postflowering photosynthetic characteristics and nitrogen distribution and grain protein components of wheat with different grain colors at maturity stage. - Chinese Journal of Wheat Crops 35(6): 829-835.

[53] Wang, S., Qi, H., Wang, Y., Zhang, Q., Feng, G., Lin, Y., Liang, Q. et al. (2016): Effects of seeding rate and seeding mode on wheat growth and development and yield under wheat-cotton intercropping mode. - Journal of Shandong Agricultural University 48(7): $39-43$.

[54] Wang, T., Qi, S., Guan, X. et al. (2013): Effects of population allocation on water utilization and yield of winter wheat. - North China Journal of Agronomy 28(2): 169174.

[55] Wang, X. C., Li, J. (2010): Evaluation of crop yield and soil water estimates using the EPIC model for the Loess Plateau of China. - Mathematical and Computer Modelling 51(1112): 1390-1397.

[56] Wei, Y. Y., Jiang, H. L., Wang, B. L. et al. (2016); Effects of different sowing methods on wheat yield in Guan Zhong area. - Anhui Agricultural Science Bulletin 22(17): $49+68$. 
[57] Xue, L., Khan, S., Sun, M., Anwar, S., Ren, A., Gao, Z., Lin, W., Xue, J., Yang, Z., Deng, Y. (2019): Effects of tillage practices on water consumption and grain yield of dryland winter wheat under different precipitation distribution in the loess plateau of China. - Soil and Tillage Research 191: 66-74.

[58] Yalçın, H., Çakır, E. (2006): Tillage effects and energy efficiencies of subsoiling and direct seeding in light soil on yield of second crop corn for silage in Western Turkey. Soil and Tillage Research 90: 250-255.

[59] Yan, C. P., Zhang, Y. Q., Zhang, D. Y., Dang, J. Y. et al. (2008); Effects of sowing date and planting density on the grain's protein component and quality of strong and medium gluten winter wheat cultivars. - J. Applied. Ecol. 19(8): 1733-40.

[60] Yan, Y. R., Hao, W. P., Bai, Q. J. et al. (2012); Study on WUE effect of water stress during jointing and grouting stage of winter wheat in North China. - Chinese Journal of Irrigation and Drainage 31(1): 46-49.

[61] Yang, J., Zhao, L., Li, S. et al. (2018); Material accumulation and distribution of wheat and the formation of grain number per panicle in response to application. - Journal of Nuclear Agriculture 32(6): 1203-1210.

[62] Ye, Q. Q., Wang, G. L., Zhu, Z. et al. (2010); Effects of nitrogen application on population dynamics, yield and soil nitrogen change of high-yield wheat. - Acta Ecologica Applicata Sinica 21(2): 351-358.

[63] Zhang, M. W. et al. (2012): Effects of Nitrogen Application on Grain Yield and Quality of Wheat. - Henan Agricultural University, Henan.

[64] Zhang, S., Lovdahl, L., Grip, H., Tong, Y., Yang, X., Wang, Q. (2009): Effects of mulching and catch cropping on soil temperature, soil moisture and wheat yield on the Loess Plateau of China. - Soil \& Tillage Research 102: 78-86.

[65] Zhang, S. L., Cai, G. X., Wang, X. Z., Xu, Y. H., Zhu, Z. L., Freney, J. R. et al. (1992): Losses of urea-nitrogen applied to maize grown on a calcareous fluvo-aquic soil in North China Plain. - Pedosphere 2: 171-178.

[66] Zhao, H. M. et al. (2013): Model of Drought-Resistant Wheat Cultivation Technology and Water Operating Mechanism. - Shanxi Agricultural University, Shanxi.

[67] Zhao, K., Chang, X., Wang, D. et al. (2019): Effects of three-dimensional uniform sowing and nitrogen application on winter wheat yield components and flag leaf photosynthetic performance. - Crop Magazine (1): 1-7.

[68] Zhao, M. X., Zhou, J. B., Yang, R., Zheng, X. F., Zhai, B. N., Li, S. X. et al. (2006): Characteristics of nitrogen accumulation, distribution and translocation in winter wheat on dryland. - J. Plant Nutrition and Fertilizer Science 12: 143-149.

[69] Zhou, X. B., Sun, S. J., Chen, Y. H. et al. (2008): Preliminary study on water characteristics and yield composition of winter wheat under different row spacing. - Acta Soilica Sinica 1: 188-191. 